\title{
Multiple Attributed Parametric Review Study on Mechanical Cotton (Gossypium hirsutum L.) Harvesters
}

\author{
Rupinder Chandel ${ }^{1} \&$ Karun Sharma ${ }^{1}$ \\ ${ }^{1}$ Department of Farm Machinery and Power Engineering, Punjab Agricultural University, Ludhiana, Punjab, \\ India \\ Correspondence: Rupinder Chandel, Department of Farm Machinery and Power Engineering, Punjab \\ Agricultural University, Ludhiana, Punjab 141004, India. E-mail: rupinder26@gmail.com
}

Received: November 21, 2021

Accepted: January 4, $2022 \quad$ Online Published: January 15, 2022

doi:10.5539/jas.v14n2p122

URL: https://doi.org/10.5539/jas.v14n2p122

\begin{abstract}
Crop characteristics of cotton are crucial to identify the important crop attributes like plant height, canopy width, sympods and monopods distribution, row spacing which affects the performance of mechanical harvesters. The activity and effectiveness of most harvest aids, including desiccants is reduced by low temperature conditions. Trash content was observed to be lesser in cotton harvested by cotton picker than cotton harvested by cotton stripper. It was found that a maximum cotton yield of $1000 \mathrm{~kg} \mathrm{acre}^{-1}$ was obtained for a cotton plant population ranging between 45,000 and 90,000 plants acre ${ }^{-1}$. Likewise, a minimum of 700 to $740 \mathrm{~kg} \mathrm{acre}^{-1}$ was observed for a cotton plant population of 33,000 plants acre $^{-1}$. In higher yielding cotton, cotton pickers recorded higher picking rate than cotton strippers. Picking/harvesting efficiency of cotton stripper with both finger and brush type mechanism was higher than the spindle type cotton picker. Picking efficiency of pneumatic picker was higher than the other types of picking mechanisms, but with lesser rate of picking capacity. Gin turnout of cotton was higher with cotton picker when compared with cotton stripper due to lesser trash content in picker harvested cotton. The horsepower requirement of cotton stripper ranged from $1 / 2$ to $1 / 4$ horsepower and cost is about two-thirds of the price as compared with cotton picker. The scheduling and monitoring of various activities involved in cotton picking by using a suitable software model can increase the benefits of both growers and harvesting companies. The reduction in uniformity with roller gin-type lint cleaners ranged between 0.2 to $0.8 \%$, which was lesser as compared with saw-type lint cleaners. Introducing mechanical harvesting has always been a decades-long process. In Turkey, it took 20 years and in Greece, this process took place very gradually over a 15 -year period. Top cotton producing countries like India, Pakistan, China, Uzbekistan and other developing countries like Iran Paraguay are still not using machine harvesting. The introduction of mechanical cotton picker or stripper can help improve quality and quantity of cotton picking thereby giving more benefit to growers in developing countries and improving their socio-economic status. The most controversial issue raised by the introduction of the mechanical cotton harvester is great migration as the machines eliminated jobs and forced poor families to leave their homes and farms in search for urban jobs. Therefore Government policies towards cotton harvesting mechanization must include the alternative jobs, packages for dependent manual cotton pickers and their families.
\end{abstract}

Keywords: cotton characteristics, mechanical cotton harvester, crop parameters, machine performance parameters

\section{Introduction}

Cotton can either be picked by machines or hand. Manual picking preserves fiber characteristics of cotton but it is a slow process and about $30 \%$ of world cotton production is harvested by machines. Boll opening is the first and gentle action and thus has no effect on the fiber quality. However, three most important fiber characters, i.e., length, strength and micronaire are affected if there is a longer stay of the open bolls in the field and also it can make the fibers shrink and may also change the color. The frequent dew can affect one character more than the other. It is possible to pick open bolls at frequent intervals with hand picking (three to four pickings/season), thus weather effects on the fiber, after bolls have opened, can be minimized. In advanced countries like USA, USSR, Egypt and Brazil, the cotton is picked by harvesters such as stripper or picker. Entire cotton picking is done manually in developing countries like India. It not involves a lot of human energy but also ten times costlier than 
cost of irrigation and about twice the cost of weeding operation (Prasad \& Majumdar, 1999). The crop characteristics and machine parameters are key elements, which play a major role in the selection, development and field performance of a mechanical cotton harvester. Hence, the research publications including crop characteristics and machine parameters were reviewed to find their effect on the performance attributes of mechanical cotton harvester for aiding in selection criteria and development of cotton harvesters in relevance to developing countries.

\section{Global Cotton Production, Harvesting and Ginning Trends}

Cotton is important component of the textile industry as it is used as natural fiber worldwide. India, China, and the United States were responsible for more than the half of the world's total production volume. In 2017, the total global production of cotton was around 120.86 million bales and total global supply of cotton, stocks included, was 248.63 million bales. The United States, with export volume of 15.5 million bales of in 2017 was leading in 2017 followed by countries like India, Brazil, and Australia. Bangladesh, Vietnam, and China were among the leading importers for their production of large quantities of cotton clothing (Shahbandeh, 2018).

Fibers are used in the textile industry as they are a raw material for production chain and use of cotton has a long tradition in the clothing industry due to its desirable characteristics. The cotton fiber is obtained from the cotton plant where it grows around seed of cotton plant and then spun into yarn. Then the cotton yarn is knitted or woven into fabric and cloths made of this fiber are are known for their long durability, have a good drape and exhibits moisture-absorbent property. Due to cotton's light and comfortable qualities, the cotton products like highly absorbent bath towels over bed linens to basic clothes such as t-shirts, underwear or socks are purchased in large amounts by consumers. In the year 2018/19, cotton production in India amounted to around 5.77 million metric tons (Shahbandeh, 2019).

Table 1. Percentage of hand and machine picking in major and other developing countries and $\%$ area where defoliants are being used

\begin{tabular}{llll}
\hline Country & Hand picking & Machine picking & $\%$ area \\
\hline Argentina & 25 & 75 & $10-15$ \\
Australia & - & 100 & 100 \\
Brazil & $90-95$ & $5-10$ & - \\
China (Mainland) & 100 & - & 5 \\
Greece & 8 & 92 & 37 \\
India & 100 & - & - \\
Pakistan & 100 & - & - \\
Turkey & 100 & - & - \\
USA & - & 100 & 71 \\
Uzbekistan & $60-70$ & $30-40$ & $72-75$ \\
Israel & - & 100 & 100 \\
Bolivia & 96 & 4 & 27 \\
Bulgaria & 15 & 85 & - \\
Colombia & 65 & 35 & 4 \\
Ecuador & 97 & 3 & - \\
Paraguay & 95 & 5 & 2 \\
South Africa & $80-85$ & $15-20$ & $15-20$ \\
Spain & 5 & 95 & 92 \\
Uruguay & 30 & 70 & - \\
Zimbabwe & 95 & 5 & - \\
\hline
\end{tabular}

Source: Chaudhary (1997). 
Table 2. Cost of picking cotton

\begin{tabular}{lll}
\hline Country & US\$/ton seed cotton & US\$/ha \\
\hline Argentina (Irrigated) & 90 & 198 \\
Australia (NSW) & 53 & 225 \\
Bolivia & 81 & 159 \\
Brazil (Northeast) & 109 & 163 \\
Chad & 43 & 43 \\
China (Mainland) & 36 & 87 \\
Colombia & 123 & 245 \\
Ecuador & 97 & 176 \\
India & 113 & $79-248$ \\
Iran & 62 & 129 \\
Israel & 27 & 145 \\
Kirghizstan & 85 & 115 \\
Mexico & 98 & 385 \\
Pakistan & 55 & $79-137$ \\
Paraguay & 143 & 222 \\
Philippines & 40 & $43-76$ \\
South Africa & $60-90$ & $36-251$ \\
Spain & 138 & 471 \\
Sudan & & $116-138$ \\
Syria & 76 & 236 \\
Thailand & & 100 \\
Turkey & 40 & 120 \\
Uganda & 94 & 47 \\
Vietnam & $30-40$ & $37-55$ \\
Zimbabwe & 50 & 50 \\
\hline & & \\
& &
\end{tabular}

All cotton is picked by machines in countries like Australia, Israel and USA (Table 1), followed by Bulgaria, Greece and Spain. The percentage of machine picking and hand picking in the 10 largest cotton producing countries of the world is given in table 1. Due to the lack of maintenance facilities for pickers, machine picking has been declining in almost all republics whereas Kazakhstan and Kirghizstan have improved the maintenance facilities, and now about $70-80 \%$ of total production is picked by machines in these two countries. Since 1991, hand picking has been increasing in Turkmenistan, Azerbaijan, Tajikistan, and Uzbekistan, and it is estimated that now $60-70 \%$ of the total area is hand picked. A prototype two row stripper machine was designed in Argentina which is commercially produced now. The model Sapucay 492 is claimed to be less expensive, and the operational cost is also lower compared with other machines on the market. Distance between rows can be adjusted between 0.85-1.0 meter and picking efficiency ranges from $85-90 \%$. Last year a number of these machines were imported into Brazil. Among the major cotton producing countries of the world, Argentina and Brazil are the only countries where machine picking is expected to increase in the next few years. Turkey may also introduce machine picking in the next few years because of a labor problem which is becoming acute. In Pakistan, by end of 1980's, shortage of labor had become a problem because of doubling production in seven years. However, some experimentation work has already been performed on machine picking in Pakistan. Machine picking would probably have been introduced by now if production had not suffered due to leaf curl virus disease. Partly, the labor problem was tackled through various social incentives to the picking labor. There are many issues to be resolved before machine picking is adopted in any country. Turkey is comparatively more prepared to adopt machine picking.

In addition to some major cotton producing countries mentioned in table 1, all cotton is picked manually in Cameroon, Chad, Côte d'Ivoire, Iran, Madagascar, Mali, Myanmar, Philippines, Senegal, Sudan, Syria, Thailand, Togo, Uganda and Vietnam which involves a lot of labour cost (Table 2). The saw ginning and roller ginning status is shown in Ta le 3 for various countries. 
Table 3. System of ginning cotton in some countries

\begin{tabular}{lll}
\hline Country & Saw ginning & Roller ginning \\
\hline Cameroon & 100 & 100 \\
Egypt & & 60 \\
India & 40 & 15 \\
Israel & 85 & 10 \\
Madagascar & 90 & 80 \\
Myanmar & 20 & 10 \\
Philippines & 90 & 9 \\
Spain & 91 & 100 \\
Sudan & & 100 \\
Thailand & & $5-10$ \\
Togo & $90-65$ & $70-75$ \\
Turkey & $25-30$ & 100 \\
Uganda & & 2 \\
USA & 98 & $5-10$ \\
Vietnam & $90-95$ &
\end{tabular}

Source: Chaudhary (1997).

In a study, a saw gin equipment line and a high-speed roller-gin line were used for ginning four cotton cultivars. The saw gin line using an air-jet and controlled-batt saw-type lint cleaner was compared to the high-speed roller-gin line including one of three designs of lint cleaner; either of two versions of an experimental lint cleaner, of a basic design not used with commercial roller ginning, one design with a lint reclaimer and the other without the lint reclaimer or a commercially available mill-type lint cleaner. The roller-gin line produced lint with better fiber length properties, lesser fiber damage, fewer neps as compared to the saw gin line. Though the experimental lint cleaner did not remove as much non-lint material but measurements of the negative effects were significantly lower than for the controlled-batt lint cleaner. The mill-type cleaner did little damage to the lint and removed even less material but added still fewer neps than the experimental lint cleaner. The reclaimer was not needed as in experiment results it was observed that it had no effect on processed fiber quality and material removal (Byler \& Delhom, 2012). In a review study under categories mobility and steering, sensing and localization, path planning, and robotic manipulation, opportunities and challenges for 21 st-century robotic agricultural cotton harvesting research and commercial development were reviewed. The paper reviews opportunities present in the agricultural robotics industry, and a detailed analysis was conducted for the cotton harvesting robot industry. The review was done on general agricultural robotic operations, to check the current robotic technologies in agriculture; opportunities and advances in related robotic harvesting fields, which is focused on investigating robotic harvesting technologies; status and progress in cotton harvesting robot research, which concentrates on the current research and technology development in cotton harvesting robots; and challenges in commercial deployment of agricultural robots, where challenges to commercializing and using these robots. The development of multipurpose robots that can do multiple operations on different crops to increase the value of the robots was discussed (Kadeghe et al., 2020). The results revealed that input energy in cotton production was $49.73 \mathrm{GJ} \mathrm{ha}^{-1}$ of which diesel energy consumption was $31.1 \%$ followed by fertilizer and machinery energy. Output-input energy ratio and energy productivity were 0.74 and $0.06 \mathrm{~kg}$ of cotton $\mathrm{MJ}^{-1}$, respectively. Cost analysis showed that net return per kilogram of seed cotton was insufficient to cover costs of production in the research area. Large farms were more successful in energy productivity, use efficiency and economic performance (Yilmaz et al., 2005). Cotton Cultivation in India occupying a big share in commercial crops is facing a major problem of picking the cotton from the plants by the labor due to increasing labor costs. Therefore, a study was done to investigate use of machine vision together with image processing and microcontrollers for identification, recognition, and processing of the cotton image as such and picking the cotton with robotic arms to yield maximum production in a day per hectare. These intelligent robots are capable to detect objects with respect to their identity, position, color, orientation in 3D pattern at the fields by use of variety of visual sensors. This paper also proposes at the new algorithms in Image processing of the cotton to extract the feature, modeling and matching. These are artificial intelligence for robotic vision, image processing for segmentation, feature measurement such as invariants, size and shape, texture and scene analysis and controlling the robotic arms in desired angle (Rao, 2013). The identification of mature cotton is one of the 
critical tasks in this robotic application. An optimized segmentation algorithm based on chromatic aberration was studied according to the statistic experiments and analysis. A new design of Intelligent Cotton Picking Robot (ICPR) was proposed based on machine vision including the motion control subsystem and machine vision subsystem. The former adopts the YASKAWA MP2100 as the core, which can control the robot of 4-DOF and $\mathrm{X}$-axis. The latter based on the interface module of SEED-VPM642 with 2-CCD cameras, can get an efficient and precise recognition. The results demonstrate that the method for cotton recognition is well done and the increased pace helps improve the speed of the processing (Wang et al., 2008).

\section{Review of Cotton Crop Characteristics and Parameters Affecting Overall Performance of Cotton Harvesters and Gins}

A parametric review study was planned for developing countries where most of the cotton is handpicked so as to encourage the use of mechanical cotton harvester in their respective regions based on crop variety and characteristics, economic conditions and availability of other facilities like gins and pre cleaners. The study aims to help researchers, manufacturers and government in formulation of policies that will encourage the design, adoption and commercialization of mechanical cotton harvesters for their respective regions based on several factors which were reviewed and presented in this paper.

\subsection{Cotton Crop Characteristics}

The characteristics of cotton variety for mechanical cotton harvesters, i.e., picker or stripper should have short height of plant with a relatively narrow space, growing in more or less upright position, fruits distributed evenly all over the plant, wide opening bolls with fluffy locks and maturity should take place early (Ahmed, 1985). Experience gleaned from the United States, Australia and XPCC indicates that the height of a cotton plant should be less than $120 \mathrm{~cm}$ for spindle-pickers and less than $80 \mathrm{~cm}$ for stripper-pickers (Williford et al., 1994) because plants that are excessively tall decrease mechanical harvesting efficiency.

\subsection{Role of Chemical Defoliants and Desiccants and Factors Affecting Their Performance on Cotton Crop}

Defoliants are used only in few countries. Defoliants cause plants to begin developing an "abscission layer", or zone of cells that eventually break down and cause leaves to separate from the stem and drop. Abscission is a natural process, but it is been enhanced by defoliant. Defoliants are classified as hormonal, herbicidal or mixtures of both. The indeterminate growth of cotton often leads to boll population at different stages of maturity when the crop is harvested. Boll opening compounds can be used as an aid in mechanical harvesting operation by accelerating the opening of green bolls. The rates of boll opening of all compounds were more influenced by the accumulation of heat units than by the amount of time following the application of boll openers. To predict and model the efficacy of boll opening with these harvest aids, heat unit accumulation may be used (Stewart et al., 2000). Defoliation timing were evaluated based on mature fruiting (sympodia) branches (MFB) and the correlation between three defoliation timing methods, heat unit (HU) accumulation after 5 nodes above white flower (NAWF5), nodes above cracked boll (NACB) and open boll percentage at defoliation (OBPD), to determine which method was the most consistent for maximizing yield, revenue and fiber quality. Delaying crop termination until after 75 OBPD had detrimental effects on fiber quality leading to quality-based discounts and reduced gross revenue (Siebert \& Stewart, 2006). Analysis of the HVI (high volume instrument) measurements showed that differences existed in Micronaire, fiber length, short fiber, fiber strength, fiber elongation, sample color, and trash levels correlated with the field and ginning treatments. The AFIS (Advanced Fiber Information System) measurements showed that there were significant differences in fiber maturity, length, short fiber, and neps correlated with the treatments. The mill cleaning reduced the differences in neps before spinning but did not eliminate the differences due to reduced fiber maturity from early defoliation. The yarn evenness was found to vary in relation to the defoliation and HVI measurements of short fiber, sample color, Micronaire and trash levels were correlated with the evenness variations. Lower yarn evenness was not found to be correlated with the ginning treatments (Byler et al., 2014).

\subsubsection{Weather and Other Factors}

It was reported that the Paraquat applications made in the late afternoon before a bright, sunny day seem to boost the effectiveness of desiccation and tend to increase regrowth control. When plant and environmental conditions are not conductive to easy defoliation, TD 1123 (potassium 3,4-dichloroisothiazole-5-carboxylate) can be an effective harvest-aid chemical on cotton (Cathey, 1985). It was reported that two chemical defoliants tank-mixed at one-half the standard use rate were equal to or superior to either single component applied at the standard use rate. Combinations offered additional safeguards against adverse environmental conditions in addition to equal effectiveness (Snipes \& Cathey, 1992). The defoliant treatments should not be applied prior to $60 \%$ open bolls in order to safeguard against potential losses in yield and undesirable changes in fiber quality (Snipes \& Baskin, 
1994).

The yield for the 38-inch row conventional with 55,000 seed/acre was greater than all seeding rates $(44,000$, 55,000 and 82,500 seed/acre) planted with twin 15-inch rows on 38-inch beds. The conventional 38-inch bed system plant height of 35 inches at harvest was equal to the twin 15-inch rows on a 38-inch bed at 44,000 seed/acre, and taller than all other bed pattern/seed rate treatments (Harrison, 2006). Results indicate that labour requirement for the developed cotton picker; the existing cotton picker and manual cotton picker at branch moisture content of 39.5\% (w.b.) and cotton moisture content of 2.8\% (w.b.)were 166.17, 173.8 and 93.3 man-h $\mathrm{ha}^{-1}$ respectively with their corresponding ground harvest losses of 15, 12 and 5\% obtained (Adebija \& Jackson, 2013).

It was reported that increased number of rows per bed in mechanical picker would result in increased harvesting losses. An increased number of rows per bed would result in narrower plants, thereby making their configuration more suitable for finger-type stripper harvesting (Batchelder et al., 1982). The effects of spacing between stripping rolls, plant size and plant moisture content were investigated on cotton harvest losses and vegetative foreign material. The total harvest loss increased when spacing between stripping rolls widened and was not affected by plant size. Stick content in harvested cotton increased as the branch moisture decreased. Spacing between stripping rolls did not significantly affect fine foreign material (Wanjura \& Brashears, 1983). Cotton harvester was reported most efficient in terms of dropping the lowest percentage on ground and picking the highest percentage of seed cotton at 107,000 to 110,000 plants/ha (Saifi \& Azizov, 1991). The view of cotton stripper, header, field operation are shown in Figures 1 and 3. The view of cotton picker drum and line diagram for cotton picker are shown in Figure 2.
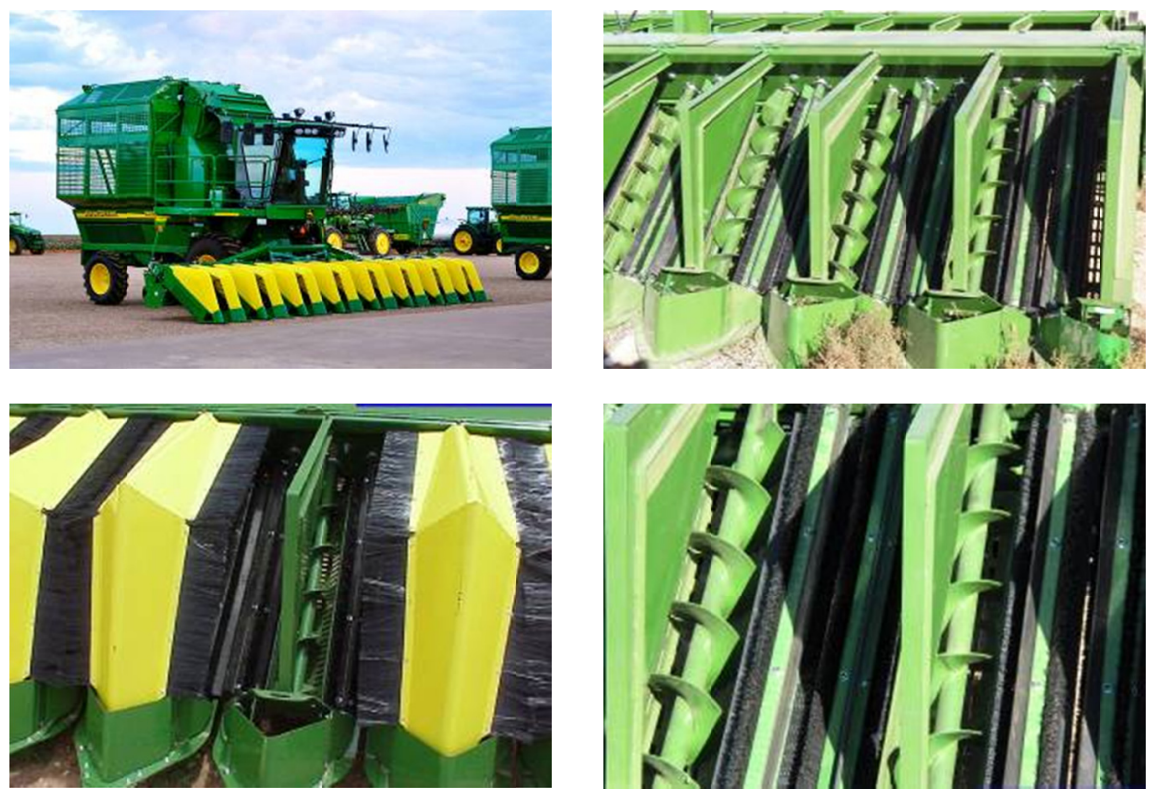

Figure 1. A view of cotton stripper and various views of header for cotton stripper
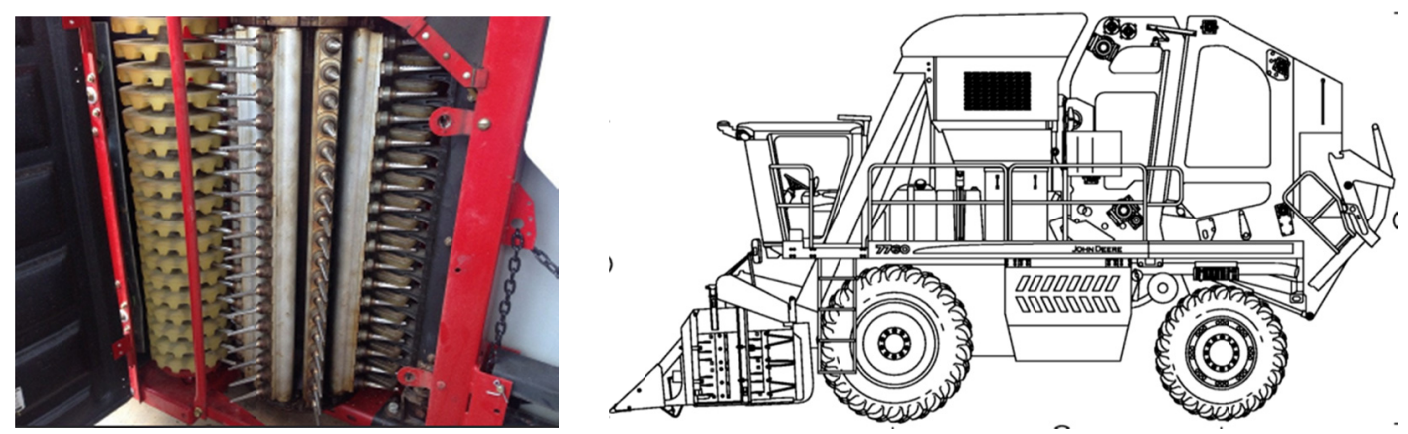

Figure 2. View of picker drum and cotton picker 


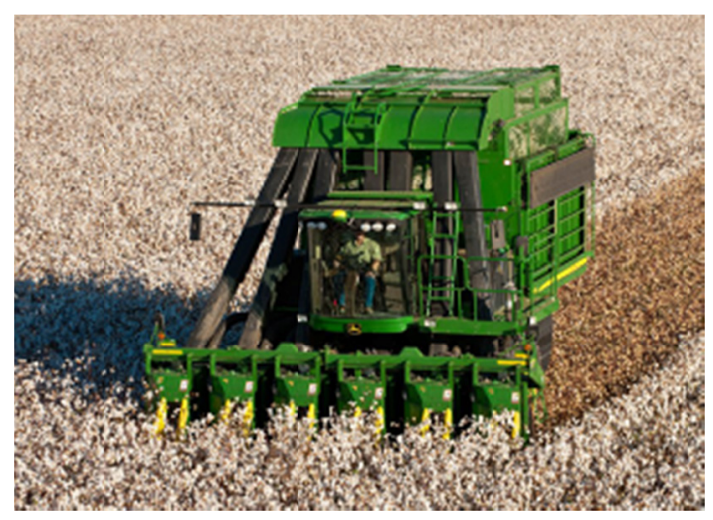

Figure 3. View of cotton stripper in operation

\subsection{Effect of Cotton Varieties, Row Spacing, Plant Population, Picking Mechanism on Crop Yield and Field Capacity/Picking Rate of Cotton Harvester}

Cotton harvesting/picking may be accomplish manually or mechanically using cotton picker. A manually operated cotton picker was developed and compared with the existing manually operated cotton picker, and the traditional method of harvesting cotton on the bases of labour requirement, time input, ground and plant harvest losses.

It was reported that cotton quality and yield were reduced in three out of five years with once over and delayed harvesting compared to twice over harvesting. The most significant factor influencing yield and grade was occurrence of rainfall after opening of the cotton balls.

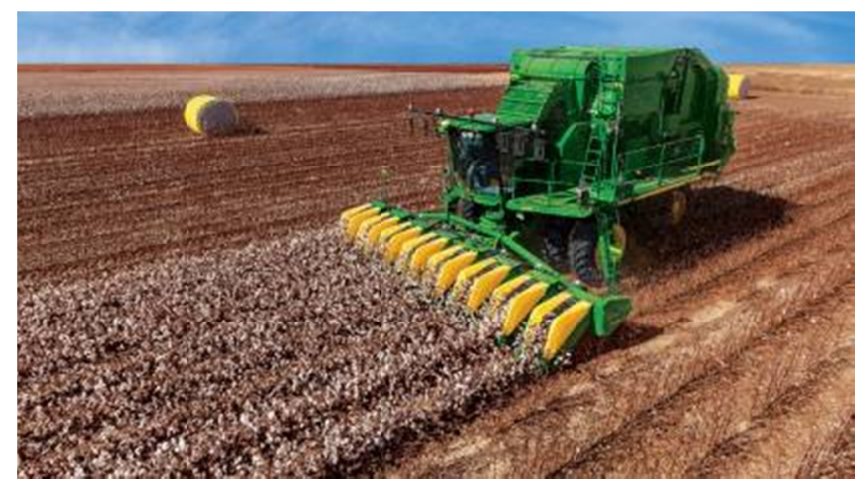

Figure 4. A view of cotton stripper during field

Cotton yield and quality were significantly reduced by rainfall totaling $50 \mathrm{~mm}$ or more. Lint yield reduced by an average of $44 \mathrm{~kg} \mathrm{ha}^{-1}$ but grade index increased by application of defoliation. Application of Prep (ethephon) at the $40 \%$ or $60 \%$ open stage to accelerate boll opening significantly reduced yield and grade but had no detrimental effect on yield or grade if applied at the $80 \%$ open stage (Williford, 1992). After reviewing other research works it was found that the cotton variety affects field capacity or the picking rate of mechanical harvesters but row spacing was having less effect on picking rate/field capacity of cotton harvester.

The self-propelled and tractor operated cotton strippers are shown in Figures 4 and 5, respectively.

In a study, cotton bolls after conditioning were subjected to a single cotton picker spindle operating at a speed of 1000 to $3000 \mathrm{rpm}$ spindle design used were: a $12.7-\mathrm{mm}(1 / 2-$ in.) round, tapered, barbed spindle and a $4.8-\mathrm{mm}$ (3/16-in.) square spindle which was straight and smooth. Mass measurements were taken to determine the portion of seed cotton not picked and the portion that would be ejected from the spindle ("fly-off") and peak force required to pull the seed cotton from the spindle was determined by a force gauge. 


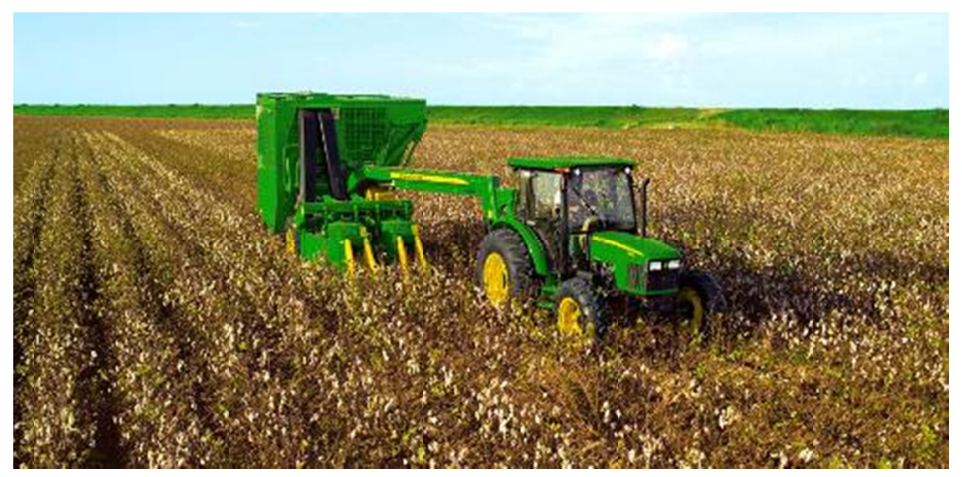

Figure 5. A view of tractor operated cotton stripper

Moisture content of the bolls ranged from $9 \%$ to $10 \%$ (d.b.). Smaller, straight spindle was more aggressive in removing cotton from the boll and the peak force required ranged from $50 \%$ to $100 \%$ more than from the barbed spindle. The fly-off from the barbed spindle was twice as much than from the smaller straight spindle at any given speed and it increased exponentially as the speed increased for each spindle type. The peak force requirement was approximately doubled each time the speed was increased by $1000 \mathrm{rpm}$ for both spindles, which indicated that there exist an exponential relationship between speed and wrap tightness (Baker et al., 2010).

Typically cotton strippers horsepower range from $1 / 2$ to $1 / 4$ and cost about $2 / 3$ the price of a cotton picker. A cotton stripper under low yield conditions also has a higher harvesting and field efficiency than a cotton picker (Porter et al., 2012). The strippers had higher productivity in terms of acres per hour than pickers, in systems where sufficient support equipment was available. Pickers had a higher productivity rate than strippers in higher yielding cotton. The picker harvest resulted in lower levels of foreign matter and therefore leads to higher turnout but had higher harvest losses (Faulkner et al., 2011b). A study was conducted to evaluate the fiber characteristics of narrow row cotton ( $0.45 \mathrm{~m}$ spacing) using harvesting Pro-12 VRS picker, brush stripper and finger stripper with and without field cleaner. The efficiency of the harvester was quantified by determining the total loss and yield. The technological fiber characteristics like Elg, Mic, +b, Trash, UHM, SFC, Rd, UI and STR were analyzed through the HVI tool. Impurities in the harvested cotton were quantified by determining the percentage of stem and bark present in the sample. Cotton in hardened management system had less trash content when harvested with the Pro-12 VRS picker, but it failed to preserve the intrinsic quality of the fiber. However, harvesting high density cotton resulted in a significantly smaller amount of waste with the Pro-12 VRS picker than with the stripper harvesting system. Field cleaner of the stripper harvester with comb and brush platforms provided cotton with a smaller amount of bark and stem (Aguero et al., 2018). The spindle picker header as shown in Figure 6 which is used on a spindle type cotton picker as shown in Figure 7 is capable of harvesting 95 to $98 \%$ of the cotton produced, but harvest losses up to $20 \%$ were experienced by some producers.

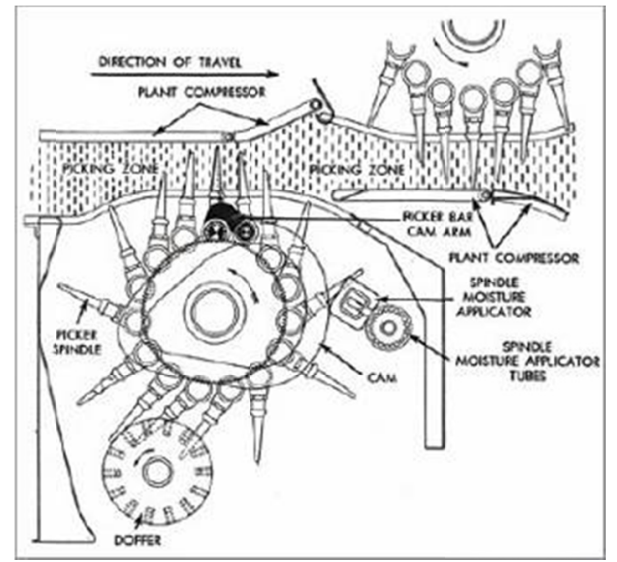

Figure 6. Working of opposed-drum cotton picker 


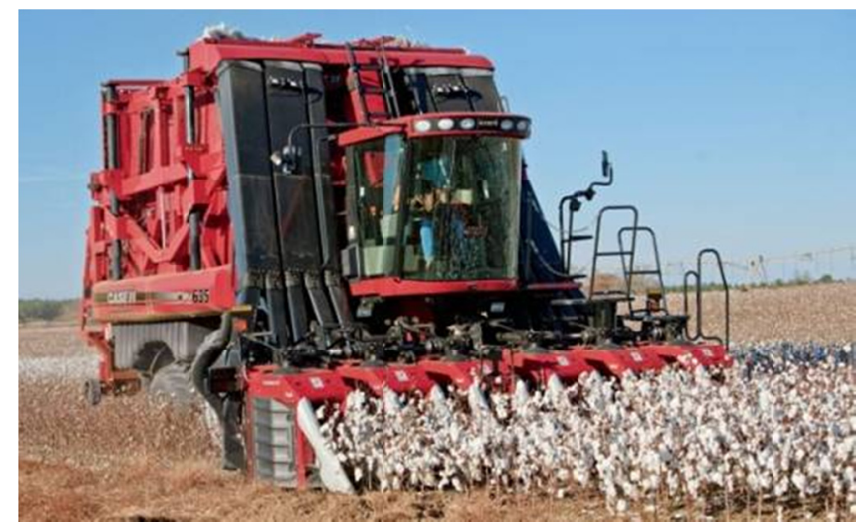

Figure 7. A spindle type cotton picker during field operation

Information gathered on the effect of different mechanisms of cotton harvester showed that the picking/harvesting efficiency of cotton stripper for both finger and brush type mechanism was higher than that of the spindle type picker. Strippers had higher productivity in terms of acres per hour than pickers in systems where sufficient support equipment was available. The picking efficiency of pneumatic picker was also higher than the other types of picking mechanisms, but at lesser rate of picking capacity. Pickers has higher productivity rate than strippers in higher yielding cotton. The cotton picker has higher harvest losses which also results in lower levels of foreign matter and therefore produces higher turnout (Willicut et al., 2010).

Effect of various row spacing, plant population on cotton yield and type of picking mechanism on cotton picking and harvest efficiency are summarized in Table 4.

\subsection{Picking Patterns and Other Arrangements}

Most efficient method practiced in the field is stopping the picker on the row and pulling the boll buggy beside it within a few seconds (about $70 \%$ of time actively harvesting) (Figure 9). The basket is then raised, unloaded and lowered and thereafter the picker resumes harvesting. In order to minimize compaction of field from the tractor and boll buggy or making ruts when the soil is wet, operators should develop picking patterns based on unloading near row ends - even if baskets are only partially full. In order to minimize the scattering of seed cotton during windy days, the basket should be unloaded into the wind.

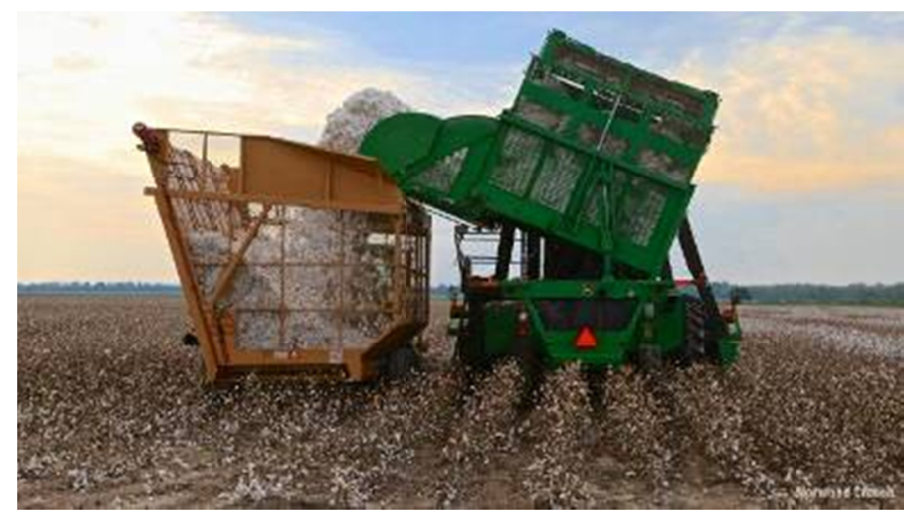

Figure 8. Conventional basket picker stops on the row and unloads into a boll buggy for greatest field efficiency Source: Willicut et al. (2010).

A field study was conducted to evaluate cotton stripper performance with variation in harvesting directions (in the rows, cross, and oblique, or skew) and row spacing (24-, 36-, and 70-cm). Minimum loss occurred in the skew treatment and maximum seed cotton loss was observed in the row direction treatment and at row spacing of $70 \mathrm{~cm}$. Overall, these results revealed that cotton harvested in a skewed or oblique direction and grown in $36-\mathrm{cm}$ rows produced seed cotton yield higher than the $70-\mathrm{cm}$ rows harvested in the rows direction and had a greater 
impact on the reduction of seed cotton losses (Roozbeh \& Zahiri, 2019). The efficiency of the picker platform with variable-row-spacing (VRS) for harvesting cotton in narrow rows was evalauted, in two regions within the state of Mato Grosso, Brazil over two harvest seasons. In this study, how the effect of scraping plates and travel speed was related to quantifiable levels of harvested fibers and impurities for various cotton varities with row spacing of $0.45 \mathrm{~m}$. The results revealed that scraping plates reduced the harvest efficiency and increased the number of stems and cones for cotton planted in narrow rows. The highest speed and the presence of the scraping plates increased the number of cones and the removal of the scraping plates decreased the amount of cones in the harvested cotton (Baraviera et al., 2017).

Table 4. Effect of various row spacing, plant population on cotton yield and type of picking mechanism on cotton picking and harvest efficiency

\begin{tabular}{|c|c|c|c|c|c|c|c|c|}
\hline $\begin{array}{l}\text { Variety and } \\
\text { timing of sowing }\end{array}$ & $\begin{array}{l}\text { Boll type } \\
\text { and mc. }\end{array}$ & $\begin{array}{l}\text { Row } \\
\text { spacing, } \\
\text { cm }\end{array}$ & $\begin{array}{l}\text { Plant } \\
\text { population/ } \\
\text { acre }\end{array}$ & $\begin{array}{l}\text { Yield } \\
\text { Kg/acre }\end{array}$ & $\begin{array}{l}\text { Picking method/ } \\
\text { spindle type rpm }\end{array}$ & $\begin{array}{l}\text { Picking eff./ } \\
\text { Harvest eff., \% }\end{array}$ & $\begin{array}{l}\text { Field capacity, } \\
\text { ha/h or lint } \\
\text { yield, } \mathrm{kg} / \mathrm{h}\end{array}$ & Reference \\
\hline \multirow[b]{2}{*}{$\begin{array}{l}\text { Carolina queen, } \\
\text { Stoneville and } \\
\text { rex smooth leaf }\end{array}$} & \multirow[b]{2}{*}{$\begin{array}{l}\text { Fluffy } \\
\text { Knotty bolls }\end{array}$} & \multirow[t]{2}{*}{96.5} & 40,000 & 1164.5 & \multirow{2}{*}{\multicolumn{2}{|c|}{$\begin{array}{ll}\text { Tapered spindles } & 80-95 \\
700-2300 & \text { Constant } \\
2300-3900 & \text { Declined } \\
4700 & 49-72 \\
700-3900 & \end{array}$}} & & Faircloth et al., 2004 \\
\hline & & & 33,000 & $700-740$ & & & & Corley, 1966 \\
\hline SJ-2, T-4852 and DSR & & $30-38$ & $35000-50000$ & 945 & Brush stripper & $\begin{array}{l}\text { and higher gin tur } \\
\text { tolerant of advers } \\
\text { and had lower fie }\end{array}$ & $\begin{array}{l}\text { seed cotton, } \\
\text { nouts, more } \\
\text { conditions } \\
\text { d losses. }\end{array}$ & Kepner et al., 1979 \\
\hline $\begin{array}{l}\text { Rex, stoneville, stripper-31, } \\
\text { D.P.L. smoothleaf }\end{array}$ & & & $45000-90000$ & $1010-1375$ & $\begin{array}{l}\text { Flexible roll type cotton stripper } \\
\text { Steep tool stripper } \\
\text { Spindle type picker }\end{array}$ & $\begin{array}{l}97.0 \% \\
95.0 \% \\
92.0 \%\end{array}$ & & Mathews \& Tupper, 1965 \\
\hline St 393, St 457 and Carmen & & 76.0 & $45000-90000$ & 1000 & $\begin{array}{l}\text { Cotton Picker } \\
\text { (Tractor mounted } 2 \text { row ) }\end{array}$ & & 0.26 & Oz \& Karayol, 2007 \\
\hline $\begin{array}{l}\text { LH } 1556, \text { CNH } 120 \text { MB, } \\
\text { CNH } 123 \text { and CNH } 155\end{array}$ & & 90.0 & & & $\begin{array}{l}\text { Spindle type picker } \\
\text { (John Deere 9935) }\end{array}$ & $\begin{array}{l}55.6-83.1 \% \text { and } \\
68.3-85.7 \%\end{array}$ & $0.28-0.56$ & Prasad et al., 2007 \\
\hline $\begin{array}{l}\text { ST 4554B2RF, } \\
\text { FM 955LLB2 and FM 9150F }\end{array}$ & & 76.0 & & & $\begin{array}{l}\text { Spindle picker } \\
\text { Stripper }\end{array}$ & & 2.1 & Faulkner et al., 2011a \\
\hline \multirow[t]{2}{*}{$\begin{array}{l}\text { P4, Sumangala, MCU12 and } \\
\text { Anjali; CNH-36, Anjali, } \\
\text { LRA-5166, AKA-8401; } \\
\text { Ankur-651 }\end{array}$} & & & & & Pneumatic cotton harvester & $\begin{array}{l}96.4 \% \text { and } \\
\left(1^{\text {st }} \text { picking }\right) \\
97.5 \% \\
\left(3^{\text {rd }} \text { picking }\right)\end{array}$ & $\begin{array}{l}4.85 \mathrm{~kg} \mathrm{~h}^{-1} \\
(\text { Sumangala)- } \\
5.2085 \mathrm{~kg} \mathrm{~h}^{-1} \\
(\mathrm{P} 4) ; 3.0 ; 4.58\end{array}$ & $\begin{array}{l}\text { Rangaswamy et al., 2006; } \\
\text { Tajuddin, 2008; } \\
\text { Sharma, } 2008\end{array}$ \\
\hline & & & & & $\begin{array}{l}\text { Cotton picker } \\
\text { Narrow row combine } \\
\text { Cotton Stripper }\end{array}$ & $\begin{array}{l}94.0 \\
89.2 \\
92.5\end{array}$ & & Perish \& Shelby, 1974 \\
\hline $\begin{array}{l}\text { Storm proof } \\
\text { cotton varieties-open-boll } \\
\text { cotton varieties }\end{array}$ & & 76.0 & & & $\begin{array}{l}\text { Brush type stripper } \\
\text { Spindle type picker }\end{array}$ & $\begin{array}{l}96.2-90.6 \\
86.2-90.4\end{array}$ & $\begin{array}{l}155 \mathrm{~kg} \mathrm{ha}^{-1} \text { and } \\
227 \mathrm{~kg} \mathrm{ha}^{-1} \\
\text { (for delayed } \\
\text { planting) }\end{array}$ & $\begin{array}{l}\text { Tupper, 1966; } \\
\text { Sappenfield et al., } 1984\end{array}$ \\
\hline
\end{tabular}

\subsubsection{Picker Drum Arrangements}

All pickers manufactured in the U.S. have two drums usually arranged in staggered or tandem, opposed drum position as shown in Figure 11. Top-to-bottom spindle contact area of about 30 inches using 18 or 20 spindles per bar is being used in current production pickers and spindles are spaced 1.625 inch along the bar. The front drum of the row unit harvests about $75 \%$ of the cotton. The function of bar cams and cam tracks is to cause spindles to enter a cotton row pointed slightly toward the rear of the picker and quickly swing to aim slightly forward as they retreat from a row. Bar travel speed must match with ground speed, causing the spindles' motion relative to the stalk to be "into" and "out of" the row to avoid damage due to spindles in the front or at the rear of the stalks. Some of the reasons for not synchronizing the bars is due to incorrect picker tire size, improper picker adjustment, belt slippage of belt-driven picker units and wrongly assembled row-unit drive components. These will lead to harvest of trashy seed cotton thereby causing excessive power and wear at the row units. The rear drum should be generally located just behind the front drum so as to prevent interference of spindle bars of spindles. However, length (weight) of the row unit should be short as possible (close to the tractor or carrier). Now row units are lengthened to allow them to nest and provide a minimum row spacing of about 28-30 inches. These machines have cam tracks, spindles, spindle nuts, left-and-right handed bars, which increases the number 
of different parts required to repair a row unit. This complex design can lead to spindles being placed in the wrong spindle nut and bar, which consequently will cause the spindle to turn in the wrong direction to wrap cotton and then be doffed. Wrong-handed spindles installed in a row unit will not pick cotton and will wear out doffer and moistening pads. Opposed drum-row units have advantage that they pick from both sides of the plant and pick a slightly greater percentage of the cotton from the stalk in some field conditions.

\subsubsection{Spindle Moistening System}

The function of the spindle moistening system is to remove plant gums and resins by constantly supplying cleaning solution onto the spindles to keep them aggressive and easier to doff. A cleaning solution mixed to the correct concentration is essential for proper function. The solution removes plant residue while seed cotton wipes the spindle, much like a dish cloth washing flatware.

\subsection{Effect of Cotton Harvesting Methods on Gin/Lint Turnout, Trash Content and Field Losses}

Machine parameters like trash content (foreign materials like sticks, burs, dust, leaves and shells etc.), lint/gin turnout and losses like pre-harvest, ground and stalk were studied by the different scientists and their works were reviewed for collecting information pertaining to machine parameters of cotton harvesters. Research carried out on field cleaners and on similar stick machines used in ginning have shown that excessive processing rates increase loss of good seed cotton and decrease cleaning efficiency (Baker et al., 1982; Kirk et al., 1970). Previous studies indicate that the optimum feed rate of these machines fall within the range of 2-2.5 bales per hour per foot of width (Wanjura et al., 2009).

Stick characteristics, which influence loose bark levels in seedcotton, harvested with either a rotating-roll or fixed, fmgertype-stripper, were measured at two locations in the harvester and on the feeder apron in the cotton gin. Stick length was longest from finger stripping and the conveying systems of both strippers reduced stick length. The percentage of the sticks classified as barky and the loose bark levels in seed cotton in the stripper basket were highest for roll stripping. A significant amount of stick breakage occurs in the conveying system of both strippers and this breakage was a contributing factor influencing the removal of bark slivers from sticks, which then became entangled in the seed cotton and ultimately in the ginned lint (Wanjura et a1., 1979). Cotton picker and cotton stripper were both evaluated with a field cleaner and the seed-cotton yield for the cotton stripper was higher giving a value of $5506 \mathrm{~kg} \mathrm{ha}^{-1}$ when compared with $4410 \mathrm{~kg} \mathrm{ha}^{-1}$ obtained for the cotton picker. The gin turnout for the cotton picker was higher (35.4\%) when compared with $30.1 \%$ that was obtained for cotton stripper. The reason for getting less gin turnout with cotton stripper was the presence of higher trash content in the harvested cotton (Wanjura et al., 2013). Modern cotton harvesters were evaluated using different cotton varieties in determining their field performance. It was observed that the field losses for cotton picker was higher with a value of $6.8 \%$ when compared with the losses of 2.0 and $1.3 \%$ observed respectively during harvesting with cotton stripper with and without field cleaner. The percent trash content including burrs, sticks, dry leaves, pin trash was higher for the cotton stripper without field cleaner than cotton stripper with cleaner. The trash content for picker was less when compared with cotton stripper. The average value of gin turnout for cotton picker recorded the highest value of $35.6 \%$ as compared to 30.2 and $26.6 \%$ obtained in the case of cotton stripper with and without field cleaner (Faulkner et al., 201b). The gin turnout of $31.4 \%$ obtained for spindle type cotton picker was the highest value obtained when compared with 23.2 and $27 \%$ obtained respectively for cotton stripper and narrow row combine (Perish \& Shelby, 1974). It was observed that trash content from stripped seed-cotton varied between 29 and 38\% which gave an average of $34 \%$ before cleaning operations (Smith \& Dumas, 1982). Trash content was measured in the range of 5.60 to $6.65 \%$ for CNH-36, Anjali, AKA-8401 cotton varieties with pneumatic picker (Tajuddin, 2008). Brush stripper and cotton picker were both evaluated to obtain their trash content values which measured 13.60 and $12 \%$ for cotton stripper and cotton picker, respectively. Gin $\operatorname{lint}^{-1}$ turnout values obtained during the operation of both stripper and cotton picker were 31.4 and $36.2 \%$, respectively. AFIS (advanced fiber information system analysis) results indicate due to increased foreign matter, neps, immature fibers, and short fibers, the quality of lint harvested with a brush stripper may be inferior to spindle-harvested lint. A better understanding of the cost and benefits of brush stripper harvesting is necessary, because mills have the right to refuse delivery of stripped cotton (Faircloth et al., 2004). A two row spindle type cotton picker was evaluated as test results revealed that the values obtained for total harvesting loss varied between 14.29 and $31.74 \%$ (Prasad et al., 2007). It was observed from the various studies conducted by different scientists on cotton harvesters that the gin turnout of cotton was higher in cotton picker than in cotton stripper but field losses were noticed more in the case of cotton picker when compared with cotton stripper. The trash content from cotton harvested by cotton picker which includes hulls, burs, leaves, sticks etc. were observed to be lesser than that of cotton harvested by cotton stripper. 
Efforts have been made by researchers to reduce the trash content from seed-cotton during cotton harvesting. It was reported that the initial trash content of the stripped material before cleaning ranged from 29-38 per cent (Smith \& Dumas, 1982). A study was conducted on the configurations of different field cleaning machines which revealed that the percentage of total trash (trash removal efficiency) from the samples ranged from 38.0 to $75 \%$ (Kirk, 1973). An air blast system installed on cotton picker head was evaluated in order to reduce seed-cotton trash content but reported no significant difference in trash content (Barker et al., 1967). An experiment was conducted to reduce the trash content of cotton stripper using pneumatic suction device. Fine material in the bur cotton was not reduced but foreign materials (trash content) up to $70 \mathrm{~kg} \mathrm{ha}^{-1}$ were removed by the pneumatic system; (Brasher and Ulich, 1986). It was reported that soil material and plant material likely account for $78.7 \pm 14.6 \%$ and $21.3 \pm 14.6 \%$, respectively of the particulate matter $(\mathrm{PM})<100 \mu \mathrm{m}$ contained in the seed cotton samples (Wanjura et al., 2006). In previous studies carried out on trash removal it was reported that spindle speeds of 3000 and $4000 \mathrm{rpm}$ had more detrimental effects on trash levels in seed cotton, cotton fiber quality and picker stalk loss than a spindle speed of $2000 \mathrm{rpm}$. It was reported that the $2000 \mathrm{rpm}$ spindle speed is optimal because trash in the seed cotton is reduced as compared with spindle speeds of 2200, 2500, and 2800 rpm, which reduces ginning costs; however; only minimal differences are present at spindle speeds up to $2800 \mathrm{rpm}$ (Baker et al., 2015). A study revealed that total harvest loss increased when spacing between stripping rolls widened but was not affected by plant size. When the branch moisture content decreased and plant height increased, the stick content in harvested cotton increased; however, stick content was lowered by increased spacing between stripping rolls. Fine foreign material was not affected by spacing between stripping rolls, branch moisture content and plant size, or. Cumulative rainfall between the first freezing temperature and harvest was the most important parameter for predicting quantity of sticks in harvested cotton. However, spacing between stripping rolls was the most important variable in explaining total harvest loss (Wanjura \& Brashears, 1983). The cotton fiber quality begins to degrade naturally with the opening of the boll and mechanical harvesting processes are perceived to exacerbate fiber degradation. Previous research carried out revealed that cotton harvested by cotton stripper generally has lower fiber quality, average lower length, uniformity, strength, micronaire and higher foreign matter content than cotton picker. Tests were conducted to evaluate the influence of wire belt conveyor on seed cotton cleanliness and fiber quality. Fiber quality and foreign matter content from the wire belt conveyor were comparable to those of bur cotton conveyed by a standard cross auger. The results did not favour either the standard or the wire belt cross auger, revealing that the wire belt conveyor must be optimized to perform better than the cross auger (Porter et al., 2015). The self-propelled horizontal spindle type pickers of high capacity are most commonly available and these need to be run in more than 150-200 ha per season for meeting the economical picking standard under Turkish condition. However, agricultural lands in Turkey are fragmented and mostly small (averaging $6 \mathrm{ha}$ ). Therefore, field trials of tractor mounted pickers were held at $0.76 \mathrm{~m}$ inter-row spacing at four locations using three different cotton varieties (Stoneville 457; Stoneville 393 and Carmen-Fibermax). Results revealed that plant condition, field condition and defoliation were effective on the quantitative performance results and developed picker recorded an average of 3\% ground loss under suitable conditions. There was no significant effect between the treatments (hand and mechanical picking) and fiber quality values (Erdal, 2014). The cultural practices and staggered blooming characteristics of present Indian cotton varieties poses challenge to engineers in the mechanization of cotton picking. In a study, performance evaluation of a two-row self-propelled cotton picker John Deere 9935 was conducted at different locations in India. It was evaluated at CICR Nagpur and PAU Ludhiana on seven varieties/genotypes, namely CNH $120 \mathrm{MB}$, CNH 123, CNH 155, CNH 911, CNH 2713, CNH 4736 and GSH 2. The average plant height of $85.9 \mathrm{~cm}, 86.0$ $\mathrm{cm}, 98.1 \mathrm{~cm}, 81.9 \mathrm{~cm}, 73.2 \mathrm{~cm}, 77.8 \mathrm{~cm}$ and $86.3 \mathrm{~cm}$ and height of lowermost boll were $9.0 \mathrm{~cm}, 10.9 \mathrm{~cm}, 21.6$ $\mathrm{cm}, 11.6 \mathrm{~cm}, 16.4 \mathrm{~cm}$ and $12.3 \mathrm{~cm}$ for CNH $120 \mathrm{MB}, \mathrm{CNH}$ 123, CNH 155, CNH 911, CNH 2713, CNH 4736 and GSH 2, respectively and PAU Ludhiana variety LH 1556 had an average plant height of $112.9 \mathrm{~cm}$. The mean values of forward speed, effective field capacity, total harvesting loss, mechanical picking efficiency and picker efficiency were $2.62 \mathrm{~km} \mathrm{~h}^{-1}, 0.28 \mathrm{ha} \mathrm{h}^{-1}, 23.62 \%, 75.7 \%$ and $76.4 \%$, respectively at PAU, Ludhiana. The values of forward speed, effective field capacity, fuel consumption, total harvesting loss, mechanical picking efficiency and picker efficiency observed at CICR, Nagpur varied from 2.20 to $3.38 \mathrm{~km} \mathrm{~h}^{-1}, 0.278$ to $0.563 \mathrm{ha} \mathrm{h}^{-1}, 22.0$ to $24.01 \mathrm{~h}^{-1}, 14.29$ to $31.74 \%, 55.6$ to $83.1 \%$ and 68.3 to $85.7 \%$, respectively (Prasad et al., 2007). In the case of stripper and equipment combinations with bur-extractors for farm size of about 364 ha (900 ac), the four-row stripper had the least cost, followed by the six-row stripper for farm sizes ranging between 405 and 486 ha $(1,000$ and 1,200 ac) and the eight-row stripper for minimum farm size of 526 ha $(1,300 \mathrm{ac})$. In case of stripper and equipment combinations without bur-extractors, the four-row stripper had the least cost of harvesting for farm size of about 486 ha (1,200 ac), followed by the six-row stripper for farm size ranging between 526 and 607 ha $(1,300$ and 1,500 ac) and the eight-row stripper for minimum farm size of $648 \mathrm{ha}(1,600 \mathrm{ac})$. The average cost 
of harvesting for picker and equipment combinations, was minimized by the two-row picker and equipment combination up to 243 ha $(600 \mathrm{ac})$. The four and six row picker and equipment combinations became optimum between 283 and 486 ha (700 and 1,200 ac) and at about 526 ha (1,300 ac) respectively (Nelson et al., 2001).The reason for getting less gin turnout with cotton stripper was the presence of higher trash content in the harvested cotton. The trash content for picker was less as compared to cotton stripper. The scenario of gining in various countries shows that India is the leading country with the highest number of roller gins and USA has adopted $98 \%$ saw gining system and rest as roller gining. The cost of ginning was found highest at US\$549/ton of lint for Sudan as shown in Figure 9.

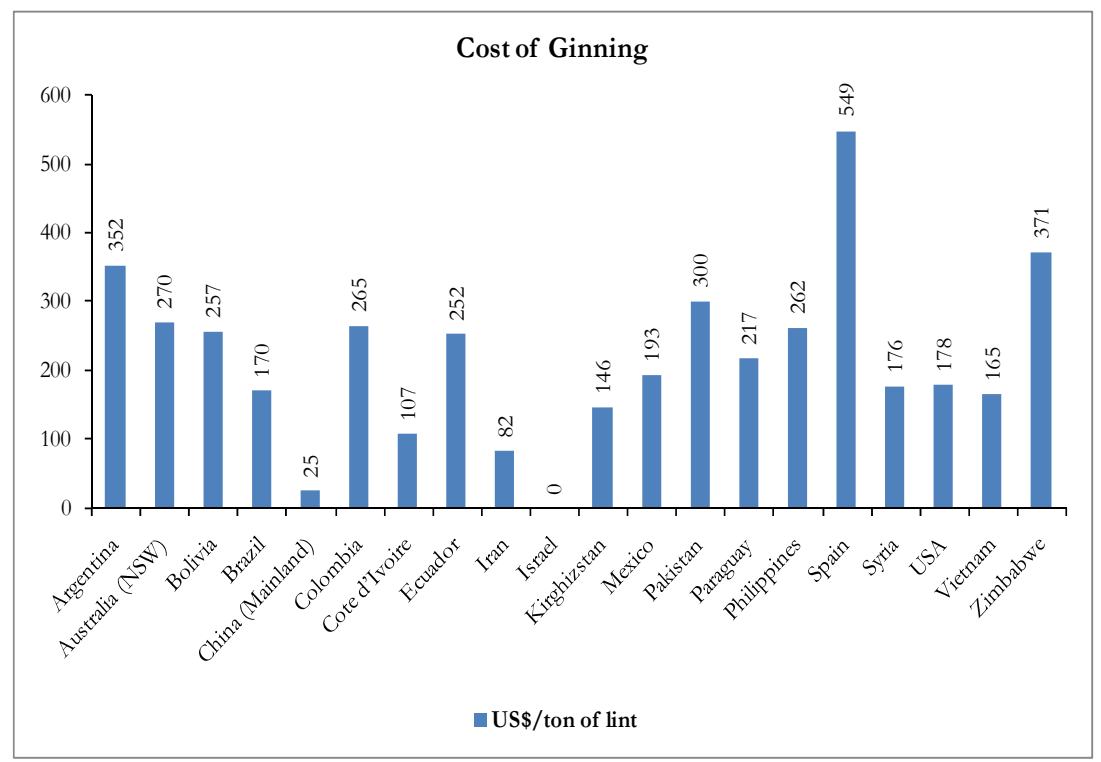

Figure 9. Cost of ginning in different countries of world

Source: Chaudhary (1997).

However, a high percentage of impurities were found in the cotton samples $(>1.0)$ harvested by a brush stripper with and without field cleaner and a finger stripper without field cleaner (Lamas, 2004; Faircloth et al., 2004) Even in small amounts neps can affect textile quality and cotton marketability. Neps are fiber entanglements created during the mechanical processing of cotton and are often associated with immature fibers. Various factors contributing to neps are more immature bolls at harvest, machine harvesting and lower fiber linear density (fineness). A study was conducted to compare machine spindle and hand-harvested cotton collected. Differences in the percentage of immature bolls and fiber linear density were generated by systematically varying the timing of harvest aids to cease crop growth, removing fruiting branches, or both. The spindle harvesting increased neps in all studies, but there were no significant statistical interactions between the harvest method with harvest aid timing or branch removal treatments. Spindle harvesting increased neps by an average of 53 count/g compared to hand harvesting. Identifying reasons for differences in nep levels between cotton growing regions may assist in developing strategies to reduce neps (Bange \& Long, 2013). A study was done to compare the average fiber quality and the variability of quality between bales of cotton produced by Deere 7760 spindle harvester with on board module building capacity producing round modules and conventional spindle basket harvesting with separate module building method. There was no significant difference of average results between the two harvest methods for upper half mean length and bundle strength determined by High Volume Instrument (HVI). However, round harvesters being able to harvest more fiber (including immature fiber from the top of plants) and less trash, therefore HVI micronaire was marginally yet significantly lower and HVI reflectance higher for fiber from this system. The normalized variability (\% coefficient of variation) of fiber quality between bales was greater for the round module system, which was attributed to less blending during the sequential ginning of round modules in contrast to the vertical building of equivalent multiple (round module) layers of seed cotton in larger conventional modules that undergo more blending when fed longitudinally into the gin (Slujis, Long, \& Bange, 2015).

The impact of the harvesting method using brush-roll stripper and spindle picker machine, as well as the ginning 
method (saw or high-speed roller ginning), on textile quality was studied over three years of cotton production. Different harvesting methods lead to differences in length distribution, color, micronaire, maturity, and non-lint content within the bale. To determine the impacts of harvesting and ginning methods on textile product quality, lint was processed into rotor-spun, carded ring-spun and combed ring-spun medium count yarns. The carded ring-spun yarns showed statistical differences in quality, with spindle-picked cottons having greater uniformity and higher tenacity while rotor spinning produced comparable quality yarns regardless of harvest or ginning method. For stripper-harvested cottons, combing was able to eliminate any functional differences in quality due to the pre-mill handling of the cottons at the expense of increased noil levels. There were no differences in ends-down during ring spinning, regardless of harvest and ginning method, although cottons produced with high-speed roller ginning were able to be spun at higher spindle speeds, which equates to higher production speeds (Slujis, 2015). It was observed from the various studies conducted by different scientists on cotton harvesters that the gin turnout of cotton was higher in cotton picker than in cotton stripper but field losses were noticed more in the case of cotton picker when compared with cotton stripper. The trash content from cotton harvested by cotton picker which includes hulls, burs, leaves, sticks etc. were observed to be lesser than that of cotton harvested by cotton stripper. Schematic diagram of cleaner for stripped cotton and gin plant are shown in Figures 10 and 11, respectively.

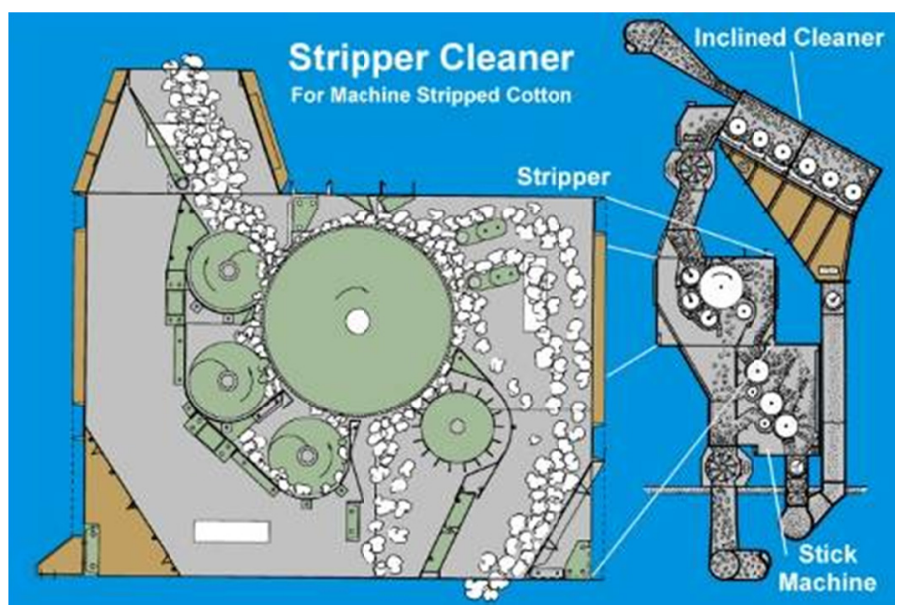

Figure 10. Cleaner for stripper picked cotton

Source: http://www.bajajngp.com/images/pdf-new/sc.jpg

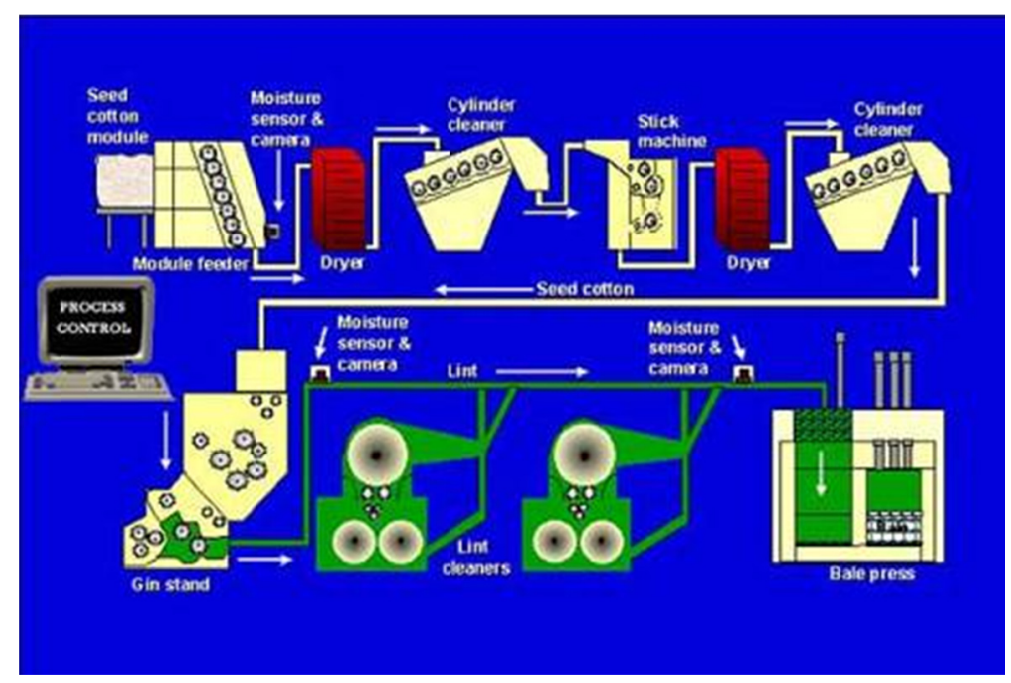

Figure 11. Line diagram for gin plant

Source: https://commons.wikimedia.org/wiki/File:Ginplant.jpg 

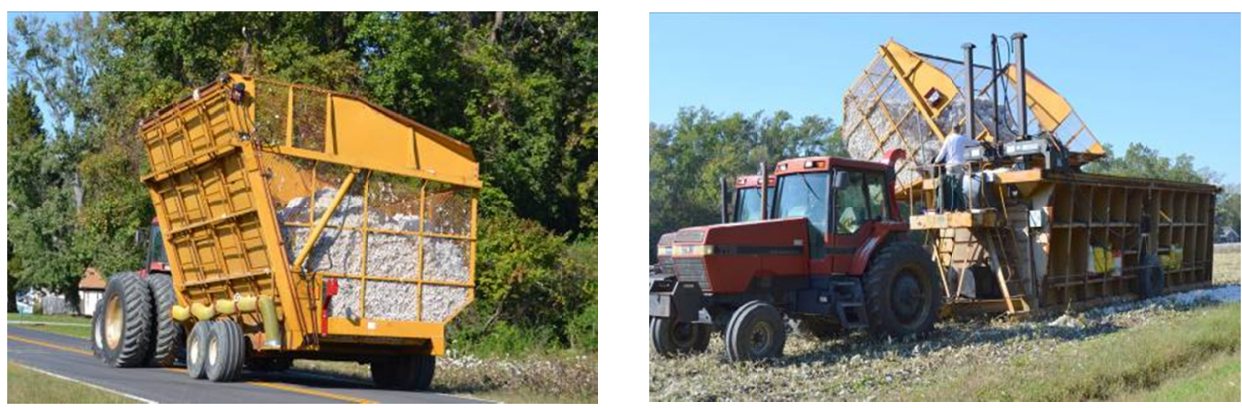

Figure 12 Cotton unloading from a boll buggy to module builder
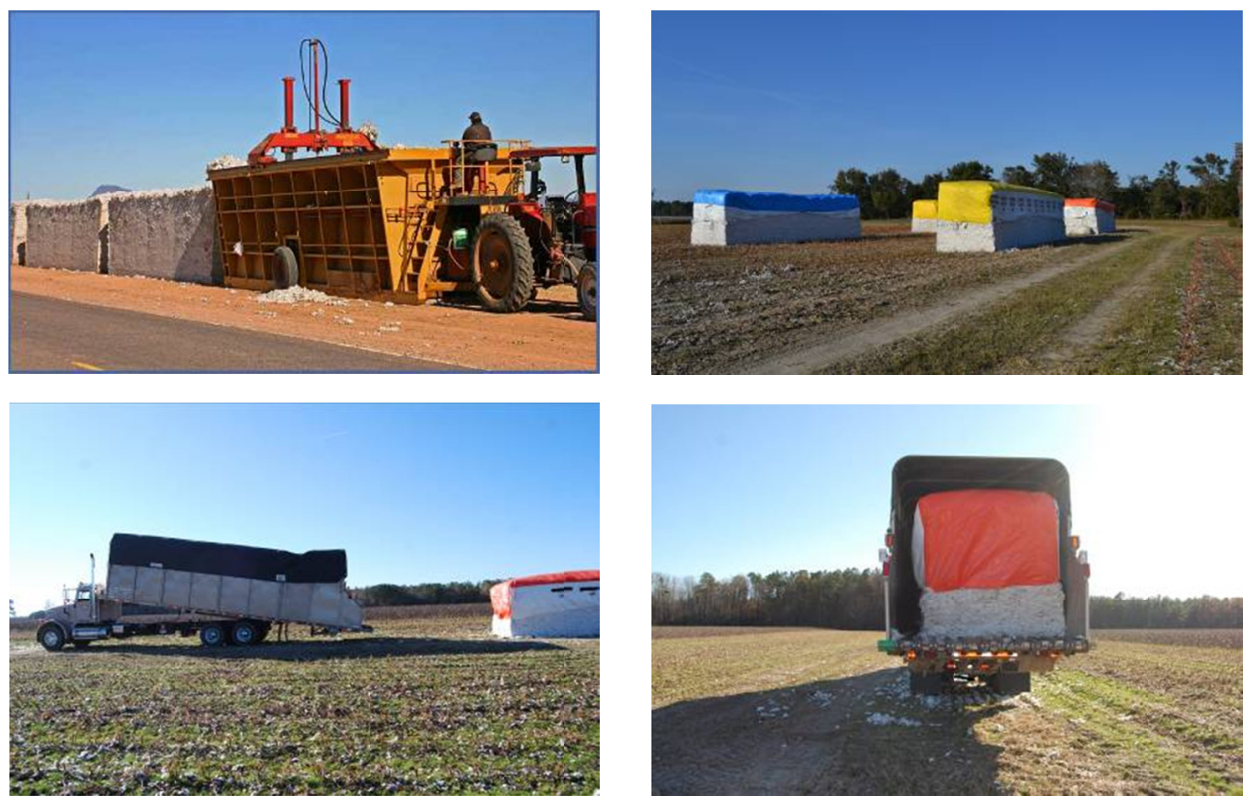

Figure 13. Cotton compressing in a module builder and transportation from field to gin

Similarly the collected cotton in boll buggy is unloaded in module builder as shown in Figure 12. The compact brick of seed cotton, weighing in at approximately 21,000 lb (16 un ginned bales created by module builder can be stored in field or in the "gin yard" until it is ginned (Figure 13). In recent years some gins have installed equipment to reclaim the fiber in the material removed by the seed cotton cleaners. Data and samples collected showed that about $8.6 \mathrm{~kg}(19.0 \mathrm{lb}$.) of material was reclaimed from the seed cotton cleaners per bale and most of the cleaned material was motes and loose lint with little seed cotton. The quality of overall reclaimed fibrous material $(<2 \%)$ was of lower than the lint obtained from the seed cotton but included a considerable amount of valuable fiber. The possible differences due to cultivar were detected and no differences were detected by HVI or AFIS in bale lint quality, in the amount of card waste, or in measurements of yarn quality made from the cotton depending on whether this reclaimed material was mixed with the seed cotton before being ginned or not. Thus the inclusion of this material in cotton bales is not recommended until additional data with additional gin equipment installations and cotton cultivars has been collected and analyzed (Byler \& Delhom, 2013). A study summarized results of harvesting and ginning studies within the past fifteen years that included High Volume Instrument (HVI) fiber length uniformity index (uniformity) which revealed that there is a need to develop cotton ginning methods that better preserve length uniformity, a fiber characteristic that is critical with newer, more efficient air-jet spinning technology. Saw ginning reduced uniformity more than did roller ginning, from 0.8 to $2.0 \%$. Moisture restoration before lint cleaning partially mitigated $(0.5 \%)$ lint cleaning's decrease in uniformity. The studies concluded that cultivar was an important determining factor and production practices, such as early defoliation and stripper harvesting, could also reduce uniformity. Uniformity was not adversely affected by seed cotton cleaning machinery (cylinder cleaners and stick machines). Uniformity was negatively affected by the saw-type lint cleaner, from 0.4 to $1.1 \%$ per stage. Studies reviewed in this report suggest that 
most of the decrease in uniformity occurs at the saw-type lint cleaner feed bar. Although uniformity was not affected by lint cleaner grid bars, faster lint cleaner saw cylinder speeds did reduce uniformity. Roller gin-type lint cleaners reduced uniformity 0.2 to $0.8 \%$, which was less than the reduction caused by saw-type lint cleaners (Armijo et al., 2019).

\subsection{Effect of Time of Planting on Harvesting of Cotton}

Cotton quality favours harvesting low-moisture cotton. Picker efficiency is generally higher for high-moisture cotton. The delayed planted cotton in $76 \mathrm{~cm}$ wide rows when harvested with brush stripper produced 24 per cent more lint than the conventional system of early planted cotton in $96 \mathrm{~cm}$ wide rows when harvested with spindle picker. It was also reported that cotton harvested using brush stripper with $76 \mathrm{~cm}$ wide rows produced 16 per cent more lint than the spindle picker with $96 \mathrm{~cm}$ wide rows when used for cotton harvesting (Sappenfield et al., 1984).

\section{Other Aspects of Mechanical Picking}

The overall stripper overall efficiencies were 3.4 to 8.2 per cent higher when stripping storm proof varieties as compared with open - boll varieties which averaged 96.2 and 90.6 per cent, respectively. The overall efficiencies of spindle-picker averaged 86.2 and 90.4 per cent for storm proof and open boll varieties, respectively. It was reported that the machine losses were 221.4 and 83.8 pounds of clean seed cotton per acre for cotton picker and cotton stripper, respectively. It was also reported that harvesting efficiencies ranged from 98.5 per cent (high) to 95.5 per cent (low) (Tupper, 1966). It was reported that picker losses were less than pre-harvest losses or weather losses and picker efficiency was strongly correlated with overall efficiency, boll diameter, dry boll weight, carpel flare of the degree of boll opening but not with number of bolls per unit weight and the equalized picker losses trash content. Lint percent was positively correlated with picker efficiency and picker yield. However the overall efficiency was strongly correlated with pre-harvest loss, which decreased as picking energy increased and there was a leveling off effect for high picking energies. Seed weight was positively correlated with picking energy and negatively correlated with picker efficiency. Weather losses were minimized by picking twice, however, peduncle length and bon length were negatively correlated with picker efficiency for twice-over picking, but not for once-over picking. The boll shape was positively correlated with pre harvest loss and negatively correlated with boll weight. There was a positive correlation of boll shape and picker efficiency indicating that pointed bolls were picked more efficiently than the rounder bolls. Maturity which is expressed as the percent of harvested yield obtained on the first picking was positively correlated with picker efficiency, but negatively correlated with picking energy (Corley, 1970). Industrial demand for fiber length is higher than 28 mm (Freddi et al., 2014). A cotton-picker operation scheduling system (CPOSS) which is a WebGIS based management software, was developed for dispatching machines and labours and guide the labours to the target field. The whole scheduling process consists of three modules and overall scheduling module aims to help the general manager to create fleet groups according to total operation demands of customers and the supply capacity of its own company. The local scheduling module was to dispatch the machines and labors to the fleet. Different cotton-picker needs different numbers of labors, CASE cotton-picker need one additional security person. The Google Maps based APP software was developed for center navigating, which receives the guidance commands from the CPOSS by SMS (GSM short message) and initiated the app to create the optimal path for the driver with the handhold mobile phone. The preliminary application of model and system shows that these can improve the management efficiency of cotton picking operation (Wu et al., 2015).

For scale cotton-picker operation, combination of production resources including field, machine, and drivers should be organized reasonably both in temporal and spatial dimensions. A cotton-picker operation scheduling and monitoring system (CPOSMS) was developed for Xinjian Agri. which is a WebGIS and BeiDou based management software including four main function modules. Based on operation demands and operation capacity, module aims to create machine fleets for the farms to help the company scheduling whereas to dispatch machines and personnel to form machine unit there is local scheduling module. The function of operation monitoring module is to monitor and analyze operation process whereas central navigating module is to guide staff to specific field. It was revealed that the CPOSMS is the necessary tool for the company and the evaluation model and BeiDou based system can improve management efficiency (Wu et al., 2016). In overall, proper model can help reduce chances of losses at different stages of cotton picking which will increase the benefits to growers by proper scheduling of different activities and management of different operations timely. To address the progressive increase in farmed land and the decline in labor, cotton production in more developed agricultural systems has seen a movement towards larger, heavier machinery with increased capacity. Recent innovation of on-board module building technology for cotton harvesters follows this trend, which has caused concern for the potential impact of the machine on the farming system. Emphasis should be made on the need to ensure that the 
effects of traffic-induced soil compaction are minimized. Within the Australia context, these cotton harvesters have undergone rapid adoption. Harvest rates of cotton pickers have increased with the increase in harvest frontage width from approximately $0.35 \mathrm{ha} \mathrm{h}^{-1}$ for a two-row cotton picker to $3.5 \mathrm{ha} \mathrm{h}^{-1}$ for the six-row round balers (RB) picker (Key, 1985; Willcutt et al., 2009). This is shown in Figure 1(d) based on several studies (Chen \& Baillie, 2009; Kocher et al., 1989; Kulkarni et al., 2008; Parvin \& Martin, 2005; Wanjura et al., 2013; Wilcutt, 2011). Maximizing picking efficiency (percent of cotton picked from the crop) requires plants to pass through the spindle mechanism. Field efficiency has remained close to constant for the conventional boll basket picker (BP) system using baskets for uncompressed boll capture, whereas for on-board module building (OBMB) is greater by approximately $75 \%$. Effective capacity is derived from forward speed and field efficiency and appears to be the parameter upon which mechanization had the greatest effect (Willcutt et al., 2010).

Consequently, the travel direction must be the same for that of planting. Although hand-picking is the slowest method, it is the cleanest in terms of trash content, and in developing countries, the cheapest in terms of capital outlay (Narayanan, 2005). Stripping is the fastest method but relatively less clean, whereas mechanical picking is the compromise between speed and cleanliness. Hand-picking is still the dominant method worldwide with approximately 70 to $80 \%$ of total cotton produced globally being collected manually (Wanjura et al., 2013).

\section{Potential Social Impact of Cotton Harvesters on Cotton Pickers and Farmers}

The top cotton producing countries include China, India and the United States. Cotton production has declined in United States due to soil depletion and social and economic changes and acres in this region are now mainly used for crops such as corn, soybeans and wheat. Almost all cotton production fields in Australia, Brazil, Greece, Israel, South Africa, Spain, and the United States were machine harvested and in Argentina, Bulgaria, Colombia, Kazakhstan, Mexico and Turkey, between 60 and 90 percent of cotton production fields were machine harvested. Iran and Paraguay also reported small percentages of machine harvesting as at 2013. In China, 9 per cent of total production in 2013-2014 was harvested by machine (up from 5 per cent in 1998-1999). Machine harvesting is not used in India even though production has expanded there by 37.1 million bales (around 6.29 million tons, one bale weight $170 \mathrm{~kg}$ ) over the last years (Anonymous, 2021). A hectare of cotton in Uzbekistan requires about 400 to 500 person-hours of labor to harvest by hand but only a couple of hours by machine, which is an important consideration if snow or heavy rain is anticipated. As per report of the International Cotton Advisory Committee (ICAC), it was believed that a few machines were used on 1 percent to 2 percent of the crop in Uzbekistan in the 2014. Every country that has adopted mechanical harvesting techniques did so primarily because of labour scarcity. In Argentina, machine harvesting is about one-fourth less expensive than handpicking. In Greece and Turkey, mechanization reduced the costs associated with harvesting as a share of total cotton production costs by about half, reduced contamination and shortened harvesting time. Contamination is when nonplant material (jute, polypropylene from fertilizer bags, rocks, dirt, and headscarves and other clothing) inevitably gets caught up in huge heaps of seed cotton as a result of millions of pairs of hands being involved. Data were collected in four regions that varied in terms of labor scarcity, area of land under cotton, suitability for cotton production and experience with mechanization among farmers. This was done to enable a comparison of findings across a range of conditions that are typical for Uzbekistan. The selection process was based on official statistics and information gathered from local experts. The four regions were selected, each of which represented different conditions (Swinkles, 2016).

In Greece, Turkey, and Argentina, displaced workers did not receive any compensation or adjustment assistance programs by Governments. In the three countries, most rural workers displaced by the introduction of mechanical harvesting either returned to other available agricultural jobs or found jobs in cities. The women often returned to traditional household responsibilities, while men tried to find alternative seasonal agricultural employment. In Turkey, displaced workers shifted to other agricultural sectors and continued to migrate seasonally in search of employment. Governments tend to encourage mechanization, so while mechanizing cotton harvesting government should make policies, create employment for rural youth/pickers so that their socio economic needs are also fulfilled.

\section{Conclusions}

The average seed-cotton yield for high density planting system was higher. Higher picking rate was obtained for cotton pickers than cotton strippers in higher yielding cotton. Under low yield conditions, higher field and picking efficiency were obtained for cotton stripper than cotton picker. Higher productivity rate was obtained for cotton pickers than cotton strippers in higher yielding cotton. The harvest losses were higher in picker harvest but lesser foreign matter and therefore, higher turnout. Open boll varieties showing storm resistance had high picker and stripper efficiency. In general, defoliant treatments should not be applied before $60 \%$ open bolls in 
order to safeguard against potential losses in yield and undesirable changes in fiber quality. Field losses were observed more in case of picker as compared to cotton stripper. Suitable system with software modelling technique is very beneficial in reducing various losses and increasing benefits to growers/commercial harvesting farmers/firms/companies. For the adoption of mechanical harvesters in developing countries, the Government should also make policies and create alternative employment opportunities keeping in view socio economic needs of dependent manual pickers. For mechanical harvesting the developed cotton varieties must possess traits like fruiting nodes occur on the main stem rather than on the branches, thus limiting the width of plants. Plants' hairiness (which impedes spindle picking) must be reduced. The varieties must be developed with bolls that form at least $15 \mathrm{~cm}$ above the ground to enable machinery access and should also exhibit uniform plant maturity so that at least 80 percent of potential bolls are open and ready to be picked at the same time. The crop characteristics and machine parameters are key elements which play a major role for the development and adoption of cotton harvester in cotton areas. Roller gin-type lint cleaners reduced uniformity 0.2 to $0.8 \%$, which was less than the reduction caused by saw-type lint cleaners. The purpose of this study was to collect the information regarding crop characteristics and machine performance parameters of mechanical cotton harvesters as well as their social impacts on manual cotton pickers, farmers and policies required for their adoption in developing countries. Different research works and studies, conducted by several researchers were reviewed to observe the effect of crop and performance parameters on cotton harvesters. For developing a mechanical cotton harvester, machine performance parameters like picking mechanism, picking efficiency, trash content and gin turn out and cotton crop spacing, planting system, are the important attributes which may be considered by the designer/engineers.

\section{References}

Adebija, J. A., \& Jackson, B. A. (2013). Performance evaluation of a manually operated cotton picker. African Journal of Agricultural Research, 8, 3883-3887.

Aguero, N. F., Mion, R. L., Baraviera, C. M., Martins, M. T., Crisostomo, W. L., \& Viliotti, C. A. (2018). Mechanical harvest methods efficiency and its impacts on quality of narrow row cotton. African Journal of Agricultural Research, 13(41), 2263-2268. https://doi.org/10.5897/AJAR2016.12080

Ahmed, M.H. (1985). Mechanical harvesting of cotton in the Sudan. Agricultural Mechanization in Asia, Africa and Latin America, 16, 51-53.

Anonymous. (2016). Retrieved from https://www.statista.com/topics/1542/cotton

Anonymous. (2021). Retrieved from https://www.statista.com/statistics/797627/raw-cotton-production-india

Armijo, C. B., Whitelock, D. P., Funk, P. A., \& Martin, V. B. (2019). Engineering and ginning. How Current Cotton Ginning Practices Affect Fiber Length Uniformity Index. The Journal of Cotton Science, 23, 66-77.

Baker, K. D., Hughs, E., \& Foulk, J. (2010). Cotton Quality as Affected by Changes in Spindle Speed. Applied Engineering in Agriculture, 26, 363-369. https://doi.org/10.13031/2013.29949

Baker, K. D., Hughs, E., \& Foulk, J. (2015). Spindle Speed Optimization for Cotton Pickers. Applied Engineering in Agriculture, 31, 217-225. https://doi.org/10.13031/aea.31.10687

Baker, R. V., Boving, P. A., \& Laird, J. W. (1982). Effects of processing rate on the performance of seed cotton cleaning equipment. Transactions of the ASAE, 25, 187-192. https://doi.org/10.13031/2013.33501

Bange, M. P., \& Long, R. L. (2013). Impact of harvest aid timing and machine spindle harvesting on neps in upland cotton. Textile Research Journal, 83(6), 651-658. https://doi.org/10.1177/0040517512461704

Baraviera, C. M. de C., Mion, R. L. M., Zanetoni, H. H., Aguero, N. F., Bassini, R. T., \& Viliotti, C. A. (2017). Effects of variable-row-spacing harvesting picker platform scraping plates on cotton fiber quality and quantity. Semina: Ciencias Agrarias, Londrina, 38(3), 1169-1178. https://doi.org/10.5433/1679-0359.2017 v38n3p1169

Bennett, J. M., Woodhouse, N. P., Keller, T., Jensen, T. A., \& Antille, D. L. (2015). Advances in Cotton Harvesting Technology: A Review and Implications for the John Deere Round Baler Cotton Picker. The Journal of Cotton Science, 19, 225-249.

Brashears, A. D. (1992). Configuration of brushes and bats on cotton strippers (ASAE Paper No. 921035). Presented at the 1992 Annual ASABE Meeting in Charlotte, N.C. St. Joseph, Mich.: ASAE.

Brasher A. D., \& Ulich, W. L. (1986). Pneumatic removal of fine materials from bur cotton. Trans. of ASABE, 29(1), 51-55. https://doi.org/10.13031/2013.30100 
Byler, R. K., \& Delhom, C. D. (2012). Comparison of saw ginning and high-speed roller ginning with different lint cleaners of mid-south grown cotton. Applied Engineering in Agriculture, 28(4), 475-482. https://doi.org/ $10.13031 / 2013.42076$

Byler, R. K., \& Delhom, C. D. (2013). Evaluation of fiber and yarn quality with and without seed cotton cleaner material produced in a commercial cotton gin. Applied Engineering in Agriculture, 29(5), 621-625. https://doi.org/10.13031/aea.29.9970

Byler, R. K., Delhom, C. D., Sassenrath, G., \& Krifa, M. (2014). Fiber damage related to maturity and processing (ASABE-CSBE/ASABE Joint Meeting Presentation Paper No. 141912745). Annual International Meeting Sponsored by ASABE Montreal, July 13-16, 2014, Quebec, Canada.

Cathey, G. W. (1985). Conditioning cotton for increased response to defoliant chemicals. Field Crops Research, 10, 347-353. https://doi.org/10.1016/0378-4290(85)90040-1

Chaudhary, M. R. (1997). Harvesting and ginning of cotton in the world. Beltwide Cotton Conferences of the National Cotton Council of America, January, 10, 1997, New Orleans, LA.

Chen, G., \& Baillie, C. (2009). Development of a framework and tool to assess on-farm energy uses of cotton production. Energy Conversion Manag, 50(5), 1256-1263. https://doi.org/10.1016/j.enconman.2009.01.022

Corley, T. E. (1966). Basic factors affecting performance of mechanical cotton picker. Transactions of the ASAE, 9, 326-332. https://doi.org/10.13031/2013.39967

Corley, T. E. (1970). Correlation of mechanical harvesting with cotton plant characteristics. Transactions of the ASAE, 13, 768-773. https://doi.org/10.13031/2013.38715

Faircloth, J. C., Hutchinson, R., Barnett, J., Paxson, K., Coco, A., \& Price, P. (2004). An evaluation of alternative cotton harvesting methods in Northeast Louisiana-A comparison of the brush stripper and spindle harvester. The Journal of Cotton Science, 8, 55-61.

Faulkner, W. B., Wanjura, J. D., Boman, R. K., Shaw, B. W., \& Parnell, C. B. (2011a). Evaluation of modern cotton harvest systems on irrigated cotton: economic returns. Applied Engineering in Agriculture, 27, 515-522. https://doi.org/10.13031/2013.38198

Faulkner, W. B., Wanjura, J. D., Boman, R. K., Shaw, B. W., \& Parnell, Jr. C. B. (2011b). Evaluation of modern cotton harvest systems on irrigated cotton: harvester performance. Applied Engineering in Agriculture, 27, 497-506. https://doi.org/10.13031/2013.38196

Freddi, O. da S., Stoquero, A., \& Peres, F. S. C. (2014). Saturação do solo por bases na produtividade e qualidade de fibra do algodoeiro. Nativa, 02(01), 06-12. https://doi.org/10.14583/2318-7670.v02n01a02

Harrison, M. P. (2006). Narrow row spindle picker cotton response to bed systems and seeding rates (pp. 1665-1667). Beltwide Cotton Conferences, January 3-6, 2006, San Antonio, Texas.

Kadeghe, G. F., Wesley, M. P., Edward, M. B., \& Glen, C. R. (2020). An Extensive Review of Mobile Agricultural Robotics for Field Operations: Focus on Cotton Harvesting. Agri Engineering, 2, 150-174. https://doi.org/10.3390/agriengineering2010010

Kepner, R. K., Curley, R. G., Brooks, C. R., \& Walhood, V. T. (1979). A brush type stripper for double row cotton. Transactions of the ASAE, 22, 1234-1237. https://doi.org/10.13031/2013.35190

Key, H. A. (1985). Cotton picker development and field performance (Vol. 85, Issue 1572). ASAE 1985 Winter Meeting, Chicago, IL, December 17-20, 1985, ASABE, St. Joseph, MI.

Kirk, I. W. (1973). Optimizing saw-grid cleaner design for cotton stripper harvesters. Transactions of the ASAE, 446-449. https://doi.org/10.13031/2013.37539

Kirk, I. W. Corley, T. E., \& Kummer, F. A. (1970). Performance relations for a saw grid seed cotton cleaner. Transactions of the ASAE, 13, 171-176. https://doi.org/10.13031/2013.38563

Kocher, M. F., Walker, J. T., Matthews, E. J., \& Shackelford, P. S. (1989). Energy inputs to cotton production in Arkansas. Applied Eng. Agric., 5(3), 297-306. https://doi.org/10.13031/2013.26516

Kulkarni, S. S., Espinoza, L., Ismanov, M., \& Griffin, T. (2008). Comparison of soil compaction patterns by on-board module builders. Recorded Presentations, Beltwide Cotton Conf., January 8-11, 2008, Nashville, TN. Natl. Cotton Counc. Am., Memphis, TN. Retrieved July 15, 2015, from http://ncc.confex.com/ncc/ 2008/techprogram/p7841.htm

Lamas, F. M. (2004). Características da Fibra de Algodão Produzida nas Regiões Norte e Nordeste de Mato 
Grosso do Sul. Dourados: Comunicado Técnico, 86(1).

Mathews, E. J., \& Tupper, G. R. (1965). Coordinated development for new cotton production systems. Transactions of the ASAE, 8(4), 568-571. https://doi.org/10.13031/2013.40585

Narayanan, S. S. (2005). Cotton harvesting improvements for yield, quality, economy and efficiency. Asian Textile J., 14(9), 65-72.

Nelson, J. M., Misra, S. K., \& Brashears, A. D. (2001). Cost comparison of alternative stripper and picker cotton harvesting systems. Applied Engineering in Agriculture, 17, 137-142. https://doi.org/10.13031/2013.5455

Oz, E., \& Karayol, T. (2007). Harvesting Performance of a Tractor Mounted Mechanical Cotton Picker. Harvesting and Ginning, 1-11.

Parvin, D. W., \& Martin, S. W. (2005). The effect of recent and futuristic changes in cotton production technology on direct and fixed costs per acre (p. 18). Southern Agricultural Economics Assoc. Annual Meeting, February 5-9, 2005, Little Rock, AK. Retrieved July 15, 2015, from http://purl.umn.edu/35583

Perish, R. L., \& Shelby, K. R. (1974). Design of a cotton brush harvester for four narrow rows. Transactions of the ASAE, 17(6), 1076-1077. https://doi.org/10.13031/2013.37031

Porter, W. M., Wanjura, J. D., Taylor, R. K., \& Buser, M. D. (2012). Evaluating cotton stripper field performance. American Society of Agricultural and Biological Engineers, St. Joseph, Michigan.

Porter, W. M., Wanjura, J. D., Taylor, R. K., Boman, R. K., \& Buser, M. D. (2015). Comparison of a wire belt conveyor and cross auger conveyor for conveying of bur cotton on a stripper harvester. Applied Engineering in Agriculture, 31, 43-48. https://doi.org/10.13031/aea.31.10658

Prasad, J., \& Mujumdar, G. (1999). Present practices and future needs for mechanization of cotton picking in India. Agricultural Engineering Today, 23, 1-20.

Prasad, J., Kapur, T., Sandhar, N. S., Majumdar, G., Patil, P. G., Shukla, S. K., ... Patil, A. B. (2007). Performance evaluation of spindle type cotton picker. Journal of Agricultural Engineering, 44, 38-42.

Rangaswamy, M., Muthamilselvan, M., \& Durairaj, C. D. (2006). Optimisation of machine prameters of pneumatic knapsack cotton picker. Agricultural mechanization in Asia, Africa and Latin America, 37, 9-14.

Rao, U. S. N. (2013). Design of automatic cotton picking robot with machine vision using image processing algorithms. 2013 International Conference on Control, Automation, Robotics and Embedded Systems (CARE), December 16-18, 2013, Indian Institute of Information Technology, Design and Manufacturing, Jabalpur, India. https://doi.org/10.1109/CARE.2013.6733700

Roozbeh, M., \& Zahiri, M. (2019). Engineering and ginning. Effects of harvesting direction and row spacing on the cotton stripper performance in irrigated cotton fields. The Journal of Cotton Science, 23, 90-96.

Saifi, E., \& Azizov, M. (1991). Khlopok (Vol. 4, pp. 20-21).

Sappenfield, W. P., Boon, W. D., \& Ward, J. N. (1984). Conventional and short-season cotton production and harvesting systems. Transactions of the ASAE, 27, 1287-1291. https://doi.org/10.13031/2013.32961

Shahbandeh, M. (2018). Cotton-Statistics \& Facts. Retrieved from https://www.statista.com/topics/1542/cotton

Shahbandeh, M. (2019). Cotton production by country worldwide, 2019. Retrieved from https://www.statista. com/statistics/263055/cotton-production-worldwide-by-top-countries

Sharma, A. (2008). Design, development and field evaluation of mechanical cotton picking aid (M. Tech Thesis, Punjab Agriculture University, Ludhiana).

Siebert, J. D., \& Stewart, A. M. (2006). Agronomy and soils. Correlation of Defoliation Timing Methods to Optimize Cotton Yield, Quality, and Revenue. The Journal of Cotton Science, 10, 146-154.

Slujis, M. H. J. V. D. (2015). Impact of the ginning method on fiber quality and textile processing performance of Long Staple Upland cotton. Textile Research Journal, 85(15), 1579-1589. https://doi.org/10.1177/ 0040517515569524

Slujis, M. H. J. V. D., \& Delhom, C. (2017). The effect of seed cotton moisture during harvesting on: Part 2 yarn and fabric quality. Textile Research Journal, 87(15), 1841-1847. https://doi.org/10.1177/00405175166 59381 
Slujis, M. H. J. V. D., Long, R. L., \& Bange, M. P. (2015). Comparing cotton fiber quality from conventional and round module harvesting methods. Textile Research Journal, 85(9), 987-997. https://oi.org/10.1177/ 0040517514540770

Smith, L. A., \& Dumas, W. T. (1982). A cleaner for cotton strippers. Transactions of the ASAE, 25, $291-296$. https://doi.org/10.13031/2013.33522

Snipes, C. E., \& Cathey, G. W. (1992). Evaluation of defoliant mixtures in cotton. Field Crops Research, 28, 327-334. https://doi.org/10.1016/0378-4290(92)90018-5

Snipes, Ch. E., \& Baskin, Ch. C. (1994). Influence of early defoliation on cotton yield, seed quality, and fiber properties. Field Crops Research, 37(2), 137-143. https://doi.org/10.1016/0378-4290(94)90042-6

Stewart, A. M., Edmisten, K. L., \& Wells, R. (2000). Boll openers in cotton: Effectiveness and environmental influences. Field Crops Research, 67, 83-90. https://doi.org/10.1016/S0378-4290(00)00093-9

Swinkles, R., Romanova, E., \& Kochkin, E. (2016). Assessing the social impact of cotton harvest mechanization in Uzbekistan (pp. 1-90). Final Report by the World Bank (International Bank for Reconstruction and Development), IBRD, IDA. https://doi.org/10.1596/24371

Tajuddin, A. (2008). Development and testing of engine operated pneumatic cotton picker. Agricultural Mechanization in Asia, Africa and Latin America, 39, 37-38.

Tupper, G. R. (1966). Stripper harvesting vs. Spindle picking of open boll and experimental stripper varieties of cotton. Transactions of the ASAE, 9, 110-113. https://doi.org/10.13031/2013.39890

Wang, M., Wei, J., Yuan, J., \& Xu, K. (2008). A Research for Intelligent Cotton Picking Robot Based on Machine Vision. Proceedings of the 2008 IEEE International Conference on Information and Automation June 20 -23, 2008, Zhangjiajie, China.

Wanjura, D. F., \& Brashears, A. D. (1983). Factors influencing cotton stripper performance. Transactions of the ASAE, 26, 54-58. https://doi.org/10.13031/2013.33875

Wanjura, D. F., Baker, R. V., \& Hudspeth, E. B. (1979). Characteristics of sticks in mechanically stripped cotton. Transactions of the ASAE, 22, 233-236. https://doi.org/10.13031/2013.34996

Wanjura, J. D. Boman, R. K., Kelley, M. S., Ashbrook, C. W., Faulkner, W. B., Holt, G. A., \& Pelletier, M. G. (2013). Evaluation of commercial cotton harvesting systems in the southern high plains. Applied Engineering in Agriculture, 29, 321-332. https://doi.org/10.13031/aea.29.9884

Wanjura, J. D., Boman, R. K., Kelley, M. S., Ashbrook, C. W., Faulkner, W. B., Holt, G. A., \& Pelletier, M. G. (2013). Evaluation of commercial cotton harvesting systems in the southern high plains. Applied Eng. Agric., 29(3), 321-332. https://doi.org/10.13031/aea.29.9884

Wanjura, J. D., Holt, G. A., Byler, R. K., Brashears, A. D., \& Baker, R. V. (2009). Development of a high-capacity extractor cleaner for cotton stripper harvesters: Machine design and optimization. Applied Engineering in Agriculture, 52, 1821-1829. https://doi.org/10.13031/2013.29202

Wanjura, J. D., Searcy, S. W., Faulkner, W. B., Willcutt, M. H., Boman, R. K., Buschermohle, M. J., ... Barnes, E. M. (2010). Stripper Harvesting (pp. 1-19). Retrieved from http://www.cottoninc.com/fiber/Agricultural Disciplines/Engineering/Cotton-Harvest-Systems/Cotton-Strippers/Cotton-Stripping-Harvest.pdf

Willcutt, M. H. (2011). New cotton harvesters benefit growers. Resource: Eng. Tech. Sust. World, 18(5), 22-23.

Willcutt, M. H., Buschermohle, M. J., Barnes, E. M., To, F. D., \& Allen, P. (2009). In-field time in motion comparisons of conventional, John Deere 7760 and Case 625 Module Express cotton pickers (pp.462-476). Proc. Beltwide Cotton Conf., January 5-8, 2009, San Antonio, TX. Natl. Cotton Counc. Am., Memphis, TN. Retrieved July 15, 2015, from http:// ncc.confex.com/ncc/2009/webprogram/Paper8914.html

Willicut, M. H., Barnes, E. M., Buschermohle, M. J., Wanjura, J. D., Huitink, G. W., \& Searcy, S. W. (2010). The spindle type cotton harvester (pp. 1-38). Retrieved from http://www.cottoninc.com/fiber/agricultural disciplines/engineering/cotton-harvest-systems/cotton-pickers/spindle.pdf

Williford, J. R. (1992). Influence of harvest factors on cotton yield and quality. Transactions of the ASAE, 35, 1103-1107. https://doi.org/10.13031/2013.28706

Williford, J. R., Brashears, A. D., \& Barker, G. L. (1994). Harvesting. In W. S. Anthony \& W. D. Mayfield (Eds.), Cotton Ginners Handbook No. 503 (pp. 11-16). Washington D.C.: USDA-ARS.

Wu, C., Qiao, P., Zhao, J., Wang, J., \& Cai, Y. (2016). Evaluating model and beidou based management system 
for scale operation of cotton-pickers. Scientific Research, 7, 21-31. https://doi.org/10.4236/pos.2016.71002

Wu, C., Zhao, J., Wang, J., Zhou, L., \& Cai, Y. (2015). Model and system for cotton-picker operation scheduling (ASABE Annual International Meeting 152190305). Published by the American Society of Agricultural and Biological Engineers, St. Joseph, Michigan.

Yilmaz, I., Akcaoz, H., \& Ozkan, B. (2005). An analysis of energy use and input costs for cotton production in Turkey. Renewable Energy, 30, 145-155. https://doi.org/10.1016/j.renene.2004.06.001

\section{Copyrights}

Copyright for this article is retained by the author(s), with first publication rights granted to the journal.

This is an open-access article distributed under the terms and conditions of the Creative Commons Attribution license (http://creativecommons.org/licenses/by/4.0/). 